\title{
Potassium fertilization increases water-use efficiency for stem biomass production without affecting intrinsic water-use efficiency in Eucalyptus grandis plantations
}

\author{
Patricia Battie-Laclau a , Juan Sinforiano Delgado-Rojas ${ }^{\mathrm{b}}$, Mathias Christina ${ }^{\mathrm{c}}$, Yann Nouvellon ${ }^{\mathrm{c}, \mathrm{e}}$, \\ Jean-Pierre Bouillet ${ }^{\mathrm{b}, \mathrm{c}}$, Marisa de Cassia Piccolo ${ }^{\mathrm{a}}$, Marcelo Zacharias Moreira ${ }^{\mathrm{a}}$, \\ José Leonardo de Moraes Gonçalves ${ }^{\mathrm{b}}$, Olivier Roupsard ${ }^{\mathrm{c}, \mathrm{f}}$, Jean-Paul Laclau ${ }^{\mathrm{b}, \mathrm{c}, \mathrm{d}, *}$ \\ ${ }^{a}$ Centro de Energia Nuclear na Agricultura, Universidade de São Paulo, CEP 13400-970 Piracicaba, SP, Brazil \\ bepartamento de Ciências Florestais, Escola Superior de Agricultura Luis de Queiroz, Universidade de São Paulo, CEP 13418-900 Piracicaba, SP, Brazil \\ ${ }^{\mathrm{c}}$ CIRAD, UMR EcoESols, 2 Place Viala, 34060 Montpellier, France \\ d Departamento de Ciência Florestal, Universidade Estadual de São Paulo “Júlio de Mesquita Filho”, CEP 18610-300 Botucatu, SP, Brazil

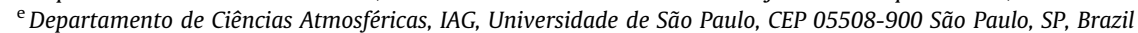 \\ ${ }^{\mathrm{f}}$ CATIE, Centro Agronómico Tropical de Investigación y Enseñanza, Turrialba 30501, Costa Rica
}

\section{A R T I C L E I N F O}

\section{Article history:}

Received 6 September 2015

Received in revised form 23 December 2015

Accepted 4 January 2016

Available online 16 January 2016

\section{Keywords:}

${ }^{13} \mathrm{C}$

Eucalypt

Leaf gas exchange

Nutrition

Water deficit

Sap flow

\begin{abstract}
A B S T R A C T
Adaptive strategies to improve tree water-use efficiency (WUE) are required to meet the global demand for wood in a future drier climate. A large-scale throughfall exclusion experiment was set up in Brazil to study the interaction between water status and potassium (K) or sodium ( $\mathrm{Na}$ ) availability on the ecophysiology of Eucalyptus grandis trees. This experiment focused primarily on the changes in aboveground net primary production, stand water use, phloem sap and leaf $\delta^{13} \mathrm{C}$, net $\mathrm{CO}_{2}$ assimilation and stomatal conductance. The correlations between these response variables were determined to gain insight into the factors controlling water-use efficiency in tropical eucalypt plantations. The intrinsic WUE in individual leaves (the ratio of net $\mathrm{CO}_{2}$ assimilation to stomatal conductance) was estimated at a very short time scale from the leaf gas exchange. Sap flow measurements were carried out to assess the WUE for stemwood production (the ratio of wood biomass increment to stand water use).

Averaged over the two water supply regimes, the stemwood biomass 3 years after planting was $173 \%$ higher in trees fertilized with $\mathrm{K}$ and $79 \%$ higher in trees fertilized with $\mathrm{Na}$ than in trees with no K and $\mathrm{Na}$ addition. Excluding $37 \%$ of the throughfall reduced stemwood production only for trees fertilized with $\mathrm{K}$. Total canopy transpiration between 1 and 3 years after planting increased from about 750 to $1300 \mathrm{~mm} \mathrm{y}^{-1}$ in response to $\mathrm{K}$ fertilization with a low influence of the water supply regime. $\mathrm{K}$ fertilization increased WUE for stemwood production by approx. $60 \%$ with or without throughfall exclusion. There was a strong positive correlation between phloem sap $\delta^{13} \mathrm{C}$ and short-term leaf-level intrinsic WUE. Whatever the water and nutrient supply regime, the gas exchange WUE estimates were not correlated with WUE for stemwood production. Phloem sap $\delta^{13} \mathrm{C}$ and leaf $\delta^{13} \mathrm{C}$ were therefore not valuable proxies of WUE for stemwood production. The allocation pattern in response to nutrient and water supply appeared to be a major driver of WUE for stemwood production. In areas with very deep tropical soils and annual rainfall $<1500 \mathrm{~mm}$, our results suggest that breeding programs selecting the eucalypt clones with the highest growth rates tend to select the genotypes with the highest water-use efficiency for wood production.
\end{abstract}

(c) 2016 Elsevier B.V. All rights reserved.

\footnotetext{
* Corresponding author at: CIRAD, UMR Eco\&Sols, 2 Place Viala, 34060 Montpellier, France.

E-mail address: laclau@cirad.fr (J.-P. Laclau).
}

\section{Introduction}

In the future, climate changes are likely to result in a reduction in rainfall in most tropical regions where fast-growing tree plantations have been established (IPCC, 2013; Hawkins and Sutton, 
2012), which will affect tree growth and patterns of water use (Wu et al., 2011). As high productivity implies high levels of water use, these planted forests are likely to be particularly affected by severe drought periods (Allen et al., 2010). Given the general increase in world demand for wood products (FAO, 2014), adaptive strategies providing both high growth potential and tolerance to water deficit are urgently needed to manage productive planted forests. Throughfall exclusion experiments using plastic panels to prevent a percentage of the total canopy throughfall from reaching the soil have been undertaken to examine the tree response to drought in temperate (e.g. Hanson et al., 2001) and tropical forests (e.g. da Costa et al., 2010). However, large-scale throughfall exclusion experiments have never been carried out in tropical planted forests to study the physiological adjustment mechanisms of trees in response to a combination of nutrient availability and water stress (Wu et al., 2011).

Tree water-use efficiency (WUE) is a critical parameter used for evaluating tree performance and exploring options for saving water (Monclus et al., 2006; Cernusak et al., 2007; King et al., 2013; Lévesque et al., 2014). Greater understanding of the mechanisms driving tree WUE is required for adapting management practices in areas subject to water shortage. Water-use efficiency is a conceptually simple parameter that, in general terms, defines the ability of the ecosystem to capture carbon and produce biomass as a function of water use. Measuring WUE is, however, methodologically challenging because this trait can be estimated in various ways and on various spatial and temporal scales (Hsiao, 1973; Binkley et al., 2004; Ripullone et al., 2004; Seibt et al., 2008). At a very short time scale, the intrinsic WUE in individual leaves $\left(\mathrm{WUE}_{i}\right.$, the ratio of the net $\mathrm{CO}_{2}$ assimilation, $A$, to the stomatal conductance, $g_{\mathrm{s}}$ ) can be calculated using measurements of the instantaneous gas exchange through the leaves (Osmond et al., 1980). Leaf WUE can also be estimated at longer time scale using the isotope signature of the carbon incorporated in the leaves over their deployment (leaf $\delta^{13} \mathrm{C}$, proxy of integrated $\mathrm{CO}_{2}$ assimilation over stomatal conductance), assuming a strong positive correlation between leaf $\delta^{13} \mathrm{C}$ and WUE $_{i}$ as observed in cereals (Farquhar and Richards, 1984) and trees (Ponton et al., 2002; Monclus et al., 2006; Cernusak et al., 2007). However, the time series of leaf $\delta^{13} \mathrm{C}$ cannot be used on its own as a reliable indicator of changes in plant WUE without independent estimates of gas exchange and environmental conditions occurring over leaf construction (Seibt et al., 2008). The phloem sap $\delta^{13} \mathrm{C}$ (proxy of crown $\mathrm{CO}_{2}$ assimilation over tree water use) has been used as an integrative indicator of short term changes (few last days) in WUE at canopy level (Cernusak et al., 2003, 2007, 2013; Keitel et al., 2003, 2006; Merchant et al., 2010; Rascher et al., 2010). As phloem sugar concentration has been found to be closely correlated with phloem sap $\delta^{13} \mathrm{C}$, phloem sugar concentration has been proposed as a reliable surrogate for phloem sap $\delta^{13} \mathrm{C}$ and, therefore, for WUE in eucalypt trees (Tausz et al., 2008). At stand scale, water-use efficiency for stemwood production, defined as the ratio of stemwood biomass increment to water transpired over the same period, is a highly integrative indicator taking into account all events occurring during biomass accumulation (Law et al., 2002). Because intrinsic WUE in individual leaves and WUE to produce wood may respond differently to environmental conditions (Lindroth and Cienciala, 1996; Binkley et al., 2004; Niu et al., 2011), WUE must be studied at various scales to provide more information on the sources of spatio-temporal variations.

WUE is implicitly sensitive to environmental conditions and consequently to environmental changes. Water and nutrient availability strongly affect growth as well as resource use efficiency and biomass partitioning in planted forests (Binkley et al., 2004; Stape et al., 2004; Beer et al., 2009; White et al., 2014). An increase in resource availability is likely to increase tree productivity and WUE for wood production by shifting the $A: g_{s}$ ratio in favor of $A$ (increasing $\mathrm{WUE}_{i}$ ) and/or by shifting biomass partitioning to aboveground tree components (Litton et al., 2007; Ryan et al., 2010). Whereas a water deficit often leads to an increase in $\mathrm{WUE}_{i}$ through stomatal closure (Bréda et al., 2006; Ainsworth and Long, 2005), it tends to lead to a decrease in WUE for wood production by increasing the fraction of the $\mathrm{CO}_{2}$ assimilated that is allocated to the roots (Litton and Giardina, 2008; Franklin et al., 2012). Olbrich et al. (1993) showed that large differences in WUE for wood production among four Eucalyptus grandis clones growing at the same site in South Africa were the result of differences in growth rates rather than transpiration rates. However, there are few comprehensive field studies combining measurements of WUE at different scales with different water supply regimes in tree plantations (White et al., 2009a, 2014; Albaugh et al., 2013). Ways of improving tree WUE in areas subject to water deficit must be found, which requires a quantitative understanding of the physiological responses to water stress (Dvorak, 2012; Marguerit et al., 2014). Nutrient supply may improve WUE in plants subject to water shortages (Cakmak, 2005). Potassium (K) and sodium (Na) fertilizations increased $\mathrm{WUE}_{i}$ in cacao plants (Gattward et al., 2012) and olive trees (Erel et al., 2014). Although high concentrations of salt in soils significantly reduce the yields of agricultural crops (Munns, 2005), Na may replace $\mathrm{K}$ for various physiological functions (Wakeel et al., 2011; Kronzucker et al., 2013; Erel et al., 2015). In a E. grandis plantation on highly weathered tropical soils, $\mathrm{K}$ and Na supply increases tree growth, wood production, leaf gas exchange and stomatal sensitivity to water deficit of trees (Battie-Laclau et al., 2014a,b), and reduces the fraction of carbon allocated belowground (Epron et al., 2012). Na supply alleviates the functional and structural limitations on $\mathrm{CO}_{2}$ assimilation rates in E. grandis trees growing in K-deficient soils (Battie-Laclau et al., 2014b), as also shown recently for olive trees (Erel et al., 2014). K and Na supply might, therefore, be an appropriate means of improving WUE for wood production where there is a shortage of water. However, the effects of $\mathrm{K}$ and Na availability on the mechanisms controlling WUE for wood production have yet to be determined.

Within the Eucalyptus genus, the highly productive E. grandis species is most commonly planted worldwide in moist, warm subtropical regions (Harwood, 2011). This study set out to gain insights into the effects of $\mathrm{K}$ and $\mathrm{Na}$ availability on the WUE of $E$. grandis trees under contrasting water supply regimes. We tested the hypotheses that (1) fertilizations that increase tree growth increase WUE for stemwood production by increasing both intrinsic WUE (the ratio of the net $\mathrm{CO}_{2}$ assimilation to the stomatal conductance in individual leaves) and aboveground biomass partitioning for stemwood production, and (2) WUE at leaf and canopy levels can be predicted from leaf and phloem sap $\delta^{13} \mathrm{C}$, as well as from sugar concentrations in phloem sap. However, the first hypothesis was only tested for the control treatment and Kfertilized trees as sap flow and consequently, WUE for wood production, were not measured for Na-fertilized trees.

\section{Materials and methods}

\subsection{Study area}

The experiment was conducted at the Itatinga Experimental Station of the University of São Paulo in Brazil $\left(23^{\circ} 02^{\prime} \mathrm{S}\right.$; $\left.48^{\circ} 38^{\prime} \mathrm{W}\right)$. Over the previous 15 years, the mean annual rainfall was $1360 \mathrm{~mm}$. The mean monthly temperature was $15^{\circ} \mathrm{C}$ during 
the dry season from June to September, and $25^{\circ} \mathrm{C}$ during the rainy season from October to May. The time series for the daily rainfall, vapor pressure deficit (VPD) and soil water content over the study period can be found in Battie-Laclau et al. (2014b).

The experimental site was located on a hilltop (slope $<3 \%$ ) at an altitude of $850 \mathrm{~m}$. The soils were very deep ferralsols ( $>15 \mathrm{~m}$ ) on Cretaceous sandstone, Marília formation, Bauru group, with a clay content ranging from $14 \%$ in the $A_{1}$ horizon to $23 \%$ in deep soil layers. The mineral content was dominated by quartz, kaolonite and oxyhydroxides and the soil was acid ( $\mathrm{pH}$ between 4.5 and 5). Exchangeable $\mathrm{K}$ and $\mathrm{Na}$ concentrations were on average $0.02 \mathrm{cmol}_{\mathrm{C}} \mathrm{kg}^{-1}$ in the upper soil layer and $<0.01 \mathrm{cmol}_{\mathrm{c}} \mathrm{kg}^{-1}$ from $5 \mathrm{~cm}$ to $1500 \mathrm{~cm}$ (Laclau et al., 2010).

\subsection{Experimental design}

A split-plot experimental design was set up in June 2010 with a highly productive E. grandis clone used in commercial plantations by the Suzano Company (Brazil). There were six treatments (three types of nutrient supply $\times$ two water regimes) replicated in three blocks. The whole-plot factor was the water supply regime ("exclusion" plots, $-\mathrm{W}$, vs "exclusion-free" plots, $+\mathrm{W}$ ) and the split-plot factor was the fertilization regime (control, C; Na fertilization, $+\mathrm{Na}$; $\mathrm{K}$ fertilization, $+\mathrm{K})$. The treatments were:

C-W: control, without $\mathrm{K}$ and $\mathrm{Na}$ fertilization, and $\sim 37 \%$ of throughfall excluded,

$+\mathrm{Na}-\mathrm{W}: \quad 0.45 \mathrm{~mol} \mathrm{Na} \mathrm{m}^{-2}$ applied as $\mathrm{NaCl}$, and $\sim 37 \%$ of throughfall excluded,

$+\mathrm{K}-\mathrm{W}$ : $0.45 \mathrm{~mol} \mathrm{~K} \mathrm{~m}{ }^{-2}$ applied as $\mathrm{KCl}$, non-limiting in terms of the availability of $\mathrm{K}$ for tree growth (Almeida et al., 2010), and $\sim 37 \%$ of throughfall excluded,

$\mathrm{C}+\mathrm{W}$ : control, without $\mathrm{K}$ and $\mathrm{Na}$ fertilization, and no throughfall exclusion,

+Na+W: $0.45 \mathrm{~mol} \mathrm{Na} \mathrm{m}^{-2}$ applied as $\mathrm{NaCl}$ and no throughfall exclusion,

$+\mathrm{K}+\mathrm{W}: 0.45 \mathrm{~mol} \mathrm{~K} \mathrm{~m}^{-2}$ applied as $\mathrm{KCl}$ and no throughfall exclusion.

The individual plots were $864 \mathrm{~m}^{2}$ in area, with 144 trees per plot at a spacing of $2 \mathrm{~m} \times 3 \mathrm{~m}$. One plot for each treatment was $50 \%$ bigger to allow destructive sampling without disturbing tree growth in the inner plots where measurements were taken. The $\mathrm{KCl}$ and $\mathrm{NaCl}$ fertilizations were applied in a single dose 3 months after planting. All the plots in the experiment were fertilized with other nutrients when the trees were planted $\left(3.3 \mathrm{~g} \mathrm{P} \mathrm{m}^{-2}\right.$, $200 \mathrm{~g} \mathrm{~m}^{-2}$ of dolomitic lime and micro nutrients) and after 3 months $\left(12 \mathrm{~g} \mathrm{~N} \mathrm{~m}^{-2}\right)$. Field trials at the study site and in nearby areas on the same type of soil showed that the amounts of $\mathrm{N}, \mathrm{P}$, $\mathrm{Ca}, \mathrm{Mg}$ and micronutrients applied in this experiment were not limiting for tree growth (Laclau et al., 2009; Gonçalves et al., 2008). The Na content of the $\mathrm{KCl}$ fertilizer was $1.0 \%$ and the $\mathrm{K}$ content of the $\mathrm{NaCl}$ fertilizer was $0.05 \%\left(<15 \mathrm{mg} \mathrm{K} \mathrm{m}^{-2}\right.$ applied in the $\mathrm{NaCl}$ fertilizer).

Throughfall was partially excluded in the $-\mathrm{W}$ plots from September 2010 onwards, using panels made of clear greenhouse plastic sheets mounted on wooden frames at heights varying between 1.6 and $0.5 \mathrm{~m}$. Plastic sheets covered $37 \%$ of the area in the $-\mathrm{W}$ plots and the throughfall exclusion amounted to $\sim 450 \mathrm{~mm} \mathrm{y}^{-1}$ in the $-\mathrm{W}$ plots. The time series of soil water content down to a depth of $6 \mathrm{~m}$ reported by Battie-Laclau et al. (2014b) showed that throughfall exclusion significantly decreased soil water storage. A scaffold tower was used to access the crown of four trees in the central part of each plot (18 towers in total in the 3 blocks).

\subsection{Biomass sampling}

Tree height and circumference at breast height $(\mathrm{CBH})$ were measured every 6 months on 36 trees within each plot (excluding a minimum of three buffer rows). The aboveground biomass was estimated at 11, 23 and 35 months by sampling eight trees representative of the range of cross-sectional areas in each treatment. The trees were separated into compartments: leaves, live branches, dead branches, stemwood (diameter $>2 \mathrm{~cm}$ at the thinner end) and stem bark. The diameters, lengths and weights were measured in the field. Subsamples were taken from all the compartments and dried until they were at constant weight. The dry biomass of each compartment in each tree was calculated proportionally to the subsamples. The foliage biomass was determined for each sampled tree by weighing all the leaves in the field and randomly subsampling 90 leaves (30 leaves from the upper, middle and lower thirds of the crown). The subsamples were then weighed again after oven drying at $65^{\circ} \mathrm{C}$ for $48 \mathrm{~h}$ to estimate the water content for each crown section. The total tree leaf biomass was obtained by summing the leaf biomass of each of the three crown sections. The dry weight of each compartment $j$ of tree $i, B_{i, j}$, was modeled as:

$B_{i, j}=c_{j}+b_{j} X_{i}^{d_{j}}+\varepsilon_{i, j}$

where $X_{i}$ is the independent variable (either $D^{2}$ or $D^{2} H$; $D$ and $H$ were, respectively, the diameter at breast height and the total tree height); $c_{j}, b_{j}$, and $d_{j}$ are the parameters to be estimated, and $\varepsilon_{i, j}$ the residual errors not explained by the models. Observations were assumed to be uncorrelated: trees in the same stand were selected as far as possible from each other to reduce potential competition between them. Eq. (1) was fitted for each age and treatment $\left(R^{2}>0.9\right.$ for most cases) using the PROC NLP procedure in SAS (see Sicard et al., 2006 for more details about the fitting steps and procedure).

Allometric equations were defined for each compartment and age and applied to the plot inventories to estimate the biomasses per hectare. The aboveground net primary production (ANPP) was assessed during the first three years after planting as the sum of the increase in aboveground biomass and the litterfall. Litterfall was collected monthly in all the plots, oven-dried at $65^{\circ} \mathrm{C}$ and weighed. There were six litter-traps $(52 \times 52 \mathrm{~cm})$ in each plot in each of the three blocks (18 litter-traps per treatment) at various distances from the trees to give a representative assessment of the litterfall. Only leaves were collected because dead branches and bark only began to fall during the fourth year after planting. Annual leaf net primary production (leaf NPP) was estimated in each plot summing the difference in leaf biomass between two successive years with the leaf litterfall over the same period.

\subsection{Leaf water potential}

The predawn leaf water potential ( $\Psi_{\mathrm{pdwn}}$, a proxy for soil water potential in the wettest soil layers explored by roots) of the four trees accessed by scaffold tower within each plot ( 72 trees in total) was measured monthly on sunny days (between 05:00 and 07:00) using a nitrogen pressure chamber (PMS Instrument Company, Albany, OR, USA). Measurements were taken on one fully expanded leaf per tree (approximately two months old) in the upper third of the canopy, on the northern side of each tree (12 leaves per treatment). Diurnal measurements of the leaf water potential $\left(\Psi_{\mathrm{w}}\right)$ were taken between 07:00 and 18:00 (five to six measurements throughout the day for all treatments in block 1) on one fully expanded leaf per tree in the upper third of the canopy, on the northern side (full sun) of each tree (four leaves per treatment and per measurement) on sunny days at 295 (2011 rainy season), 
468 (2011 dry season), 666 (2012 rainy season) and 821 (2012 dry season) days after planting.

\subsection{Leaf $\delta^{13} \mathrm{C}$}

Forty-eight fully expanded leaves approximately two months old (four leaves from each of the four trees accessed by scaffold towers in each plot) were collected between 17:00 and 18:00 for each treatment on the northern side in full sun in the upper third of the crown at 10, 16, 22 and 28 months. The leaves were ovendried at $65{ }^{\circ} \mathrm{C}$ until they reached constant weight and ground (one composite sample per plot at each sampling date) for chemical and isotopic analysis. The dried material was milled to $1 \mathrm{~mm}$ and then ashed at $550{ }^{\circ} \mathrm{C}$. The leaf $\delta^{13} \mathrm{C}$ was determined by continuous flow isotope ratio mass spectrometry (CF-IRMS), using a Thermo Delta Plus mass spectrometer (Finnigan MAT, Bremen, Germany) coupled to a Carlo Erba NC2500 elemental analyzer (CE Instruments Milan, Italy). Certified reference samples were used to check the quality of the analyses. For all plant samples, the results were expressed as parts per mil (\%o) difference from the Pee Dee Belemnite standard and calculated as follows:

$\delta^{13} \mathrm{C}=\frac{\left({ }^{13} \mathrm{C} /{ }^{12} \mathrm{C} \text { sample }-{ }^{13} \mathrm{C} /{ }^{12} \mathrm{C} \text { standard }\right)}{{ }^{13} \mathrm{C} /{ }^{12} \mathrm{C} \text { standard }} 10^{3}$

\subsection{Leaf gas exchange measurements, $W U E_{i}$ calculation}

The leaf gas exchange (net $\mathrm{CO}_{2}$ assimilation and stomatal conductance) was measured monthly on two-month-old fully expanded leaves, sampled from the north side of the canopy and in the upper third of the crown of the four trees per plot accessed by scaffold tower (in block 1). The leaf gas exchange was measured on one leaf per tree between 12:00 and 14:00 on sunny days (four leaves per treatment) at the same time as the $\Psi_{\text {pdw }}$ on adjacent leaves on the same branches. The midday net $\mathrm{CO}_{2}$ assimilation ( $\left.A_{\text {midday }}\right)$ and stomatal conductance ( $\left.g_{\text {smidday }}\right)$ were measured at a photosynthetic photon flux density (PPFD) of $>1300 \mu \mathrm{mol} \mathrm{m}{ }^{-2} \mathrm{~s}^{-1}$ (>93\% of the PPFD for light-saturated photosynthesis in E. grandis at the study site), at a near constant ambient $\mathrm{CO}_{2}$ concentration $\left(C_{\mathrm{a}} \approx 380 \mu \mathrm{mol} \mathrm{mol}{ }^{-1}\right)$ using a portable gas exchange system (LI-COR 6200, LI-COR Inc., Lincoln, NE, USA) and a $1149 \mathrm{~cm}^{3}$ chamber equipped with a LI-COR quantum sensor. The midday intrinsic WUE (WUE ${ }_{i}$ ) was calculated as the ratio of $A_{\text {midday }}$ to $g_{\text {smidday. }}$.

The diurnal time course of leaf gas exchange was needed to study the relationship between mean values of intrinsic WUE in the leaves (measured at midday every month) and WUE for wood production (photosynthesis and transpiration integrated over long periods). Diurnal measurements of leaf gas exchange were taken at the same time as the diurnal measurements of $\Psi_{\mathrm{w}}(295,468,666$ and 821 days after planting) on adjacent leaves on the same branches between 07:00 and 18:00 (five to six measurements throughout the day in all treatments in block 1) on one fully expanded leaf per tree (four leaves per treatment and per measurement).

\subsection{Collection of phloem sap and determination of total sugars concentration and $\delta^{13} \mathrm{C}$}

Phloem sap was collected routinely from a series of horizontal incisions as described by Pate and Arthur (1998) in six trees selected at random in each plot. Bulk samples of $20-40 \mu$ were collected between 16:00 and 18:00, using a series of two or three cuts around the trunk at approx. $1.3 \mathrm{~m}$ above ground level. Sap droplets were collected using a micropipette. The total sugar concentration in the phloem sap was measured immediately upon collection using a temperature-compensated hand refractometer calibrated in the range $0-32 \%(\mathrm{w} / \mathrm{v})$ sucrose (Pate and Arthur, 1998). The rest of the sap sample was kept in 1.5-ml Eppendorf vials and frozen rapidly in a portable refrigeration unit. Samples were then filtered through disposable $0.2 \mu \mathrm{m}$ Millipore filters and stored at $-20^{\circ} \mathrm{C}$ before $\delta^{13} \mathrm{C}$ analysis by CF-IRMS. The samples were lyophilized and analyzed using a Thermo Delta Plus mass spectrometer (Finnigan MAT, Bremen, Germany) coupled to a Carlo Erba NC2500 elemental analyzer (CE Instruments Milan, Italy). The $\delta^{13} \mathrm{C}$ was taken to be an integrative indicator of WUE (Farquhar et al., 1989). The analytical precision was $\pm 0.1 \%$ o (standard deviation for 20 replicate samples).

\subsection{Stand transpiration and WUE for stemwood production}

A preliminary study was carried out for $18 \mathrm{E}$. grandis trees to establish a calibration equation for the heat dissipation sensors (Granier, 1985). Three trees of different canopy classes (suppressed, intermediate and dominant) were sampled 18, 29, 45, 54,65 and 72 months after planting. The 18 trees were fitted with three sap flow sensors (length $2 \mathrm{~cm}$ ) for about one week, then cut at the bottom of the trunk (under water) and immediately placed in a bucket. The sensors were calibrated using the time series for the tree transpiration measured as the change in the water level inside the buckets over 4-6 days after cutting and the sapwood area measured by dye injection in the same trees. This preliminary study made it possible to define a single calibration equation for all the sampled trees (slope $=0.97$ and $R^{2}=0.94$ between predicted and measured values of tree transpiration, Delgado-Rojas et al., 2010).

The sap flow density $\left(v, \mathrm{~g} \mathrm{H}_{2} \mathrm{O} \mathrm{m}^{-2}\right.$ sapwood $\left.\mathrm{s}^{-1}\right)$ was measured from July 2011 to June 2013 in 10-13 trees in each treatment $(\mathrm{C}+\mathrm{W},+\mathrm{K}+\mathrm{W}, \mathrm{C}-\mathrm{W}$ and $+\mathrm{K}-\mathrm{W})$ throughout the range of crosssectional areas. Each tree was fitted with a sensor $\sim 0.2 \mathrm{~m}$ above the ground when it was 1 year old. The sap flow sensors were protected from external temperature variations and water intrusion by a reflective foil. All the sensors were moved to $\sim 1.3 \mathrm{~m}$ above the ground when the trees were 1.7 years old. The sensor output voltage was recorded every $30 \mathrm{~s}$ and the average value was stored every $30 \mathrm{~min}$ (CR1000 dataloggers and AM16/32 multiplexers, Campbell Scientific Inc., Logan, UT, USA). All the sensors were checked every 1-3 weeks and replaced if out of range readings were recorded or if they were physically damaged. The sensors were moved to newly drilled holes in another position round the trunk (selected at random) within 3 months after installation to prevent the sap flow being underestimated owing to fast tree growth. The sap flow density was calculated using the calibration equation determined in the preliminary study described above (Delgado-Rojas et al., 2010). The sapwood area $\sim 1.3 \mathrm{~m}$ above the ground was determined by injecting dye into 8 trees felled at 1 , 2 and 3 years of age in each treatment (a total of 96 trees) and the allometric relationships between the tree $\mathrm{CBH}$ and sapwood area were determined for each treatment and each age and applied to the trees being studied. The estimated sap flow for each tree was calculated as the product of the sap flow density and the sapwood area estimated from successive measurements of $\mathrm{CBH}$ over the study period. The sensors were assumed to measure the instantaneous sap velocity integrated over the average sapwood thickness of each tree.

For each tree fitted with a sap flow sensor in each treatment, the relationship between the daily total transpiration (dependent variable) and $\mathrm{CBH}^{2}$ (independent variable) was determined by linear regression (adapted from Kunert et al., 2012). Missing values (4-9\% depending on the treatment) were estimated to give a minimum of 6 values for tree transpiration per treatment and per 
day when there were sensor failures, based on regression between a simple estimate of daily evapotranspiration $\left(\mathrm{ET}_{0}\right.$; Allen et al., 1998) and measurements of daily transpiration for the same tree before and after sensor failure. The mean $R^{2}$ values for all the regressions between daily total transpiration and $\mathrm{CBH}^{2}$ over the study period were between 0.70 and 0.75 for the 4 treatments. These regressions were then used to estimate the daily stand transpiration from the $\mathrm{CBH}$ of all the trees in each inner subplot (linearly interpolated between 3 and 4 measurements of $\mathrm{CBH}$ per year).

The WUE of wood production was calculated annually in each inner subplot as the stemwood biomass produced divided by the total amount of water transpired over the same period.

\subsection{Data analysis}

Mixed-effect models were used to test the effects of water supply, fertilization, stand age, and the interactions between water supply and fertilization, water supply and tree age, and fertilization and stand age (as fixed effects) on annual aboveground net primary production (ANPP), annual leaf production, annual stemwood production, percentage of stemwood in the annual ANPP, phloem sap $\delta^{13} \mathrm{C}$, leaf $\delta^{13} \mathrm{C}$, annual stand transpiration and WUE for stemwood production. Blocks and water supply $\times$ block were considered as random effects to take account of the split-plot design. The repeated measures option was used for tree age and the residuals were modeled by a first-order autoregressive correlation model to account for the correlations between sampling dates. Linear and non linear regressions were fitted using Proc reg and Proc nlin, respectively (SAS v.9.2, Cary, NC, USA). A value of 0.05 was used as the level of significance for all tests.

\section{Results}

\subsection{Aboveground net primary production (ANPP)}

$\mathrm{Na}$ and $\mathrm{K}$ fertilization increased the ANPP over the study period by a factor of 1.5 and 2.2, respectively (Fig. 1a). A significant interaction between the water supply regime and fertilization showed that applying $\mathrm{K}$ and $\mathrm{Na}$ was less effective at increasing ANPP in $-\mathrm{W}$ plots than in $+\mathrm{W}$ plots (Table 1 ). The effects of fertilization on the annual ANPP increased with the age of the trees (there was a significant interaction between fertilization and tree age). The effects of throughfall exclusion on the ANPP also increased with tree age (the interaction between the water supply regime and tree age was significant). The effects of fertilization and the water supply regime on the leaf production increased with tree age (Fig. 1b). However, the differences between treatments were much less pronounced for the leaf production than for the ANPP and the stemwood production. The stemwood production was affected more by the fertilization regime than by throughfall exclusion, for all tree ages (Fig. 1c). The stemwood production increased from $0.12 \mathrm{~kg} \mathrm{~m}^{-2} \mathrm{y}^{-1}$ during the first year after planting to $0.85 \mathrm{~kg} \mathrm{~m}^{-2} \mathrm{y}^{-1}$ in the third year in $\mathrm{C}$ plots, but increased from $0.26 \mathrm{~kg} \mathrm{~m}^{-2} \mathrm{y}^{-1}$ in the first year to $2.38 \mathrm{~kg} \mathrm{~m}^{-2} \mathrm{y}^{-1}$ in the third year in $+K$ plots, averaged over the two water supply regimes. The fraction of ANPP partitioned to stemwood production increased from $22 \%$ in the first year after planting, to $50 \%$ in the second year and $75 \%$ in the third year on average for all treatments (Fig. 1d). The partitioning of ANPP to stemwood production was higher in fertilized plots with a significant interaction between fertilization and tree age. By contrast, the effect of throughfall exclusion on the partitioning of ANPP to stemwood production was low during the first 3 years after planting.
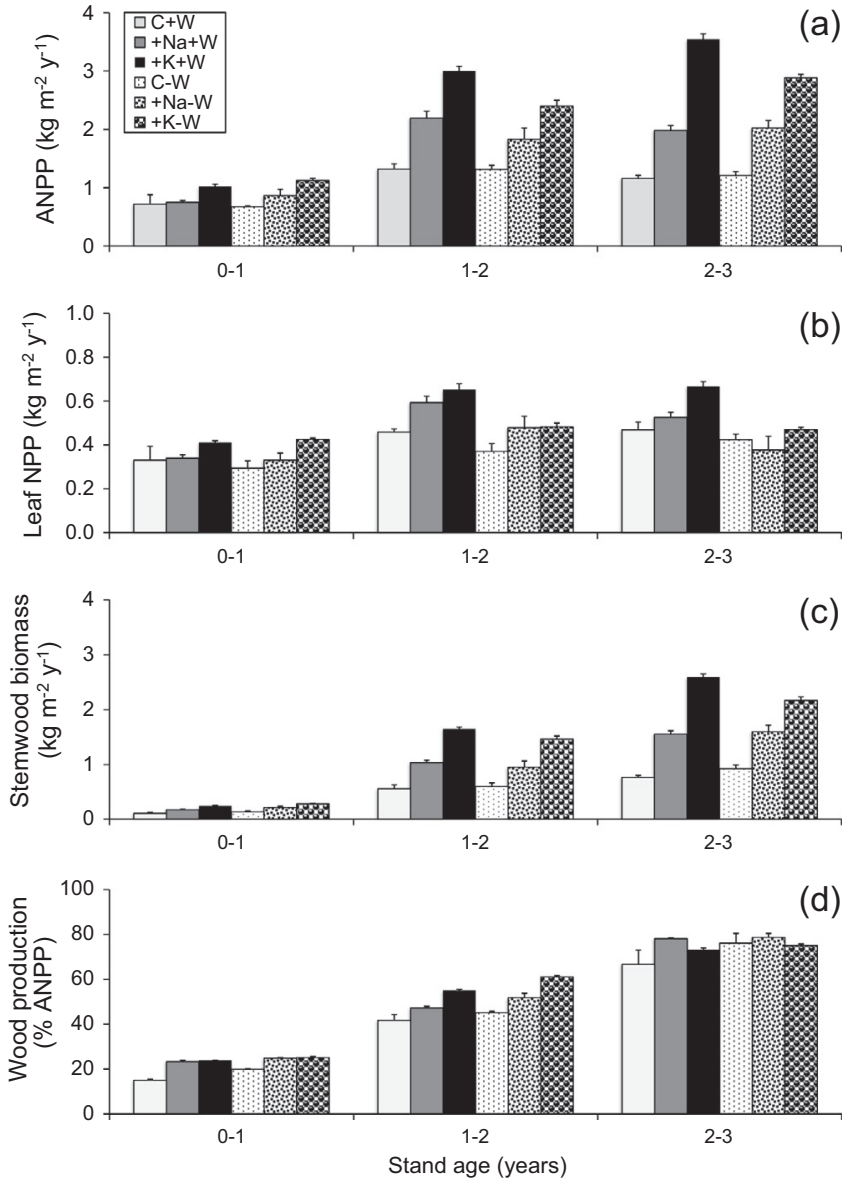

Fig. 1. Aboveground net primary production (ANPP) (a), leaf net primary production (b), stemwood production (c) and proportion of wood production in annual ANPP (d) in Eucalyptus grandis stands. $\mathrm{C},+\mathrm{Na}$ and $+\mathrm{K}$ refer to the Control, Nafertilized and K-fertilized plots respectively. $+\mathrm{W}$ and $-\mathrm{W}$ refer to undisturbed rainfall and exclusion of $37 \%$ of throughfall, respectively. Vertical bars indicate standard errors between blocks $(n=3)$.

\subsection{Stand water use}

The total annual canopy transpiration over the second and third years after planting was $739 \mathrm{~mm} \mathrm{y}^{-1}$ in $\mathrm{C}+\mathrm{W}$ plots, $1351 \mathrm{~mm} \mathrm{y}^{-1}$ in $+\mathrm{K}+\mathrm{W}$ plots, $774 \mathrm{~mm} \mathrm{y}^{-1}$ in $\mathrm{C}-\mathrm{W}$ plots and $1278 \mathrm{~mm} \mathrm{y}^{-1}$ in $+\mathrm{K}-\mathrm{W}$ plots (Fig. 2), showing that $\mathrm{K}$ fertilization had a strong effect whereas the water supply regime had a weak or moderate effect, except for the $+\mathrm{K}-\mathrm{W}$ treatment during the drought of the second year (Appendix 1). While $\mathrm{K}$ fertilization multiplied the total canopy transpiration by 1.7 for both water supply regimes over the study period, throughfall exclusion had little effect on canopy transpiration. The predawn leaf water potential reached a minimum of $-2 \mathrm{MPa}$ in $+\mathrm{K}-\mathrm{W}$ plots, at the end of the second dry season (Appendix 1). In dry periods, the canopy transpiration was reduced earlier in $+\mathrm{K}-\mathrm{W}$ than in $+\mathrm{K}+\mathrm{W}$ plots, but this effect was not seen in $-\mathrm{K}$ plots.

\subsection{Water use efficiency for stemwood production}

While $\mathrm{K}$ fertilization increased WUE for stemwood production by $60 \%$ over the second and third years after planting, throughfall exclusion had no significant effect (Fig. 3a and Table 1). Throughfall exclusion reduced WUE for stemwood production only in $+K$ plots (the interaction between the water supply regime and $\mathrm{K}$ fertilization was significant). WUE for stemwood production ranged from 
Table 1

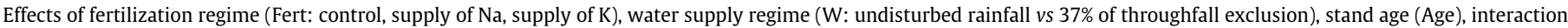

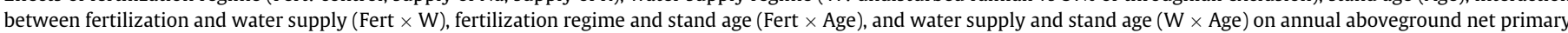

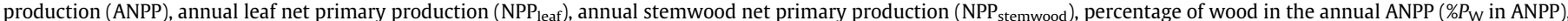

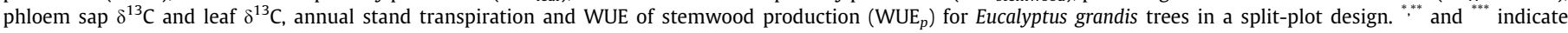
significant effects at $P<0.05,0.01$ and 0.001 , respectively.

\begin{tabular}{|c|c|c|c|c|c|c|}
\hline & Fert & $\mathrm{W}$ & Fert $\times \mathrm{W}$ & Age & Fert $\times$ Age & $\mathrm{W} \times$ Age \\
\hline ANPP & $F_{2,36}=188.36^{* * *}$ & $\mathrm{~F}_{1,2}=8.05$ & $F_{2,36}=4.77^{*}$ & $\mathbf{F}_{2,36}=327.21^{* * *}$ & $\mathbf{F}_{\mathbf{4 , 3 6}}=\mathbf{3 7 . 4 1}^{* * *}$ & $F_{2,36}=6.89^{* *}$ \\
\hline $\mathrm{NPP}_{\text {leaf }}$ & $\mathbf{F}_{2,36}=17.84^{* * *}$ & $\mathbf{F}_{1,2}=25.50^{*}$ & $\mathrm{~F}_{2,36}=0.96$ & $\mathbf{F}_{2,36}=46.55^{* * *}$ & $\mathbf{F}_{4,36}=\mathbf{2 . 8 2}$ & $\mathbf{F}_{2,36}=7.47^{* *}$ \\
\hline $\mathrm{NPP}_{\text {stemwood }}$ & $F_{2,36}=198.13^{* * *}$ & $\mathrm{~F}_{1,2}=1.14$ & $F_{2,36}=5.11^{*}$ & $\mathbf{F}_{2,36}=1031.49^{* * *}$ & $\mathbf{F}_{4,36}=\mathbf{8 4 . 9 5}^{* * *}$ & $\mathrm{~F}_{2,36}=2.48$ \\
\hline$\% P_{\mathrm{w}}$ in ANPP & $\mathbf{F}_{2,36}=20.76^{* * *}$ & $F_{1,2}=12.36$ & $\mathrm{~F}_{2,36}=1.64$ & $\mathbf{F}_{2,36}=1057.55^{* * *}$ & $\mathbf{F}_{\mathbf{4 , 3 6}}=\mathbf{7 . 9 9} * * *$ & $F_{2,36}=0.24$ \\
\hline Phloem sap $\delta^{13} \mathrm{C}$ & $\mathrm{F}_{2,106}=0.08$ & $F_{1,2}=48.83^{*}$ & $F_{2,106}=4.34^{*}$ & $\mathbf{F}_{7,106}=205.04^{* * *}$ & $\mathbf{F}_{14,106}=6.40^{* * *}$ & $F_{7,106}=11.47^{* * *}$ \\
\hline Leaf $\delta^{13} \mathrm{C}$ & $F_{2,50}=6.60^{* *}$ & $\mathrm{~F}_{1,2}=9.24$ & $\mathrm{~F}_{2,50}=0.07$ & $\mathbf{F}_{\mathbf{3 , 5 0}}=\mathbf{7 8 . 4 0 ^ { * * * }}$ & $\mathrm{F}_{6,50}=1.21$ & $\mathbf{F}_{\mathbf{3 , 5 0}}=\mathbf{3 . 0 4}$ \\
\hline Transpiration & $\mathbf{F}_{1,13}=255.62^{* * *}$ & $\mathrm{~F}_{1,2}=0.30$ & $F_{1,13}=2.39$ & $F_{1,13}=10.90^{* *}$ & $F_{1,13}=6.90^{*}$ & $F_{1,13}=9.90^{* *}$ \\
\hline $\mathrm{WUE}_{p}$ & $\mathbf{F}_{1,13}=823.67^{* * *}$ & $\mathrm{~F}_{1,2}=2.03$ & $\mathbf{F}_{1,13}=34.94^{* * *}$ & $F_{1,13}=64.81^{* * *}$ & $\mathbf{F}_{1,13}=17.91^{* * *}$ & $F_{1,13}=1.87$ \\
\hline
\end{tabular}

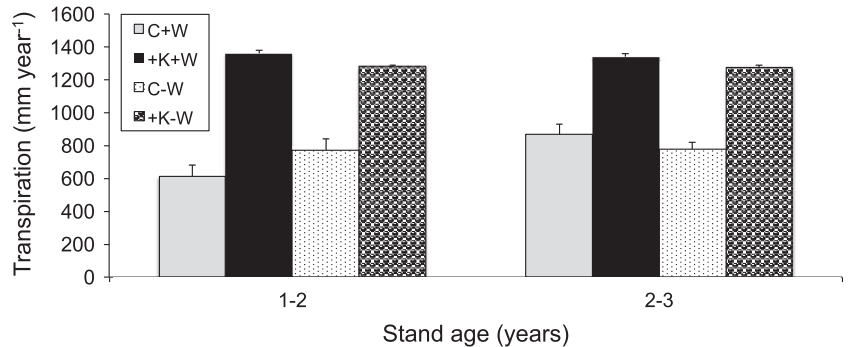

Fig. 2. Total annual canopy transpiration in the second and the third years after planting the Eucalyptus grandis trees. $\mathrm{C}$ and $+\mathrm{K}$ refer to the Control and $\mathrm{K}$-fertilized plots, respectively. $+\mathrm{W}$ and $-\mathrm{W}$ refer to undisturbed rainfall and exclusion of $37 \%$ of throughfall, respectively. Vertical bars indicate standard errors between blocks $(n=3)$.

0.8 to $1.2 \mathrm{~kg}$ of stemwood $\mathrm{m}^{-3}$ of transpired water in the second year after planting and from 0.9 to $1.9 \mathrm{~kg} \mathrm{~m}^{-3}$ in the third year, depending on the treatment. WUE for stemwood production was about $50 \%$ higher in the third year after planting than in the second year in $+K$ plots. The mean annual values of intrinsic WUE $\left(\mathrm{WUE}_{i}\right.$, the ratio of the net $\mathrm{CO}_{2}$ assimilation to the stomatal conductance in the leaves) were not correlated with WUE for stemwood production (Fig. 3b). The mean annual $\mathrm{WUE}_{i}$ values were close to $40 \mu \mathrm{mol} \mathrm{CO} \mathrm{mol}^{-1} \mathrm{H}_{2} \mathrm{O}$ for all water supply and fertilization regimes, and were not correlated with the stand ANPP (Fig. 3c).

\subsection{Phloem sap $\delta^{13} \mathrm{C}$ and leaf $\delta^{13} \mathrm{C}$}

There was a strong positive correlation between the phloem sap $\delta^{13} \mathrm{C}$ and the total sugar concentrations in the phloem sap (Fig. 4a), as well as between the phloem sap $\delta^{13} \mathrm{C}$ and $\mathrm{WUE}_{i}$ (Fig. $4 \mathrm{~b}$ ). The phloem sap $\delta{ }^{13} \mathrm{C}$ depended more on the season than the leaf $\delta^{13} \mathrm{C}$ over the study period (Fig. 4c). Phloem sap $\delta^{13} \mathrm{C}$ values were highest during the dry periods for all the treatments (467 and 830 days after planting). The effect of the treatments on the $\delta^{13} \mathrm{C}$ values was different for the leaves and phloem sap. Throughfall exclusion increased the phloem sap $\delta^{13} \mathrm{C}$, but its effect on leaf $\delta^{13} \mathrm{C}$ was not significant (Table 1). Fertilization increased the leaf $\delta^{13} \mathrm{C}$ but had no significant effect on the phloem sap $\delta^{13} \mathrm{C}$.

\subsection{Diurnal variations of leaf water potential, $g_{s}, A$ and $W U E_{i}$,}

The leaf water potential $\left(\Psi_{\mathrm{w}}\right)$ decreased early in the morning to reach minimum values at midday with a slow recovery in the afternoon (Fig. 5). The sharpest decrease in $\Psi_{\mathrm{w}}$ during the morning occurred for trees with $\mathrm{K}$ - and Na-fertilization during the dry seasons. Although the fertilization and water supply regimes strongly influenced $A$ and $g_{s}$ during the rainy season, WUE $_{i}$ was little
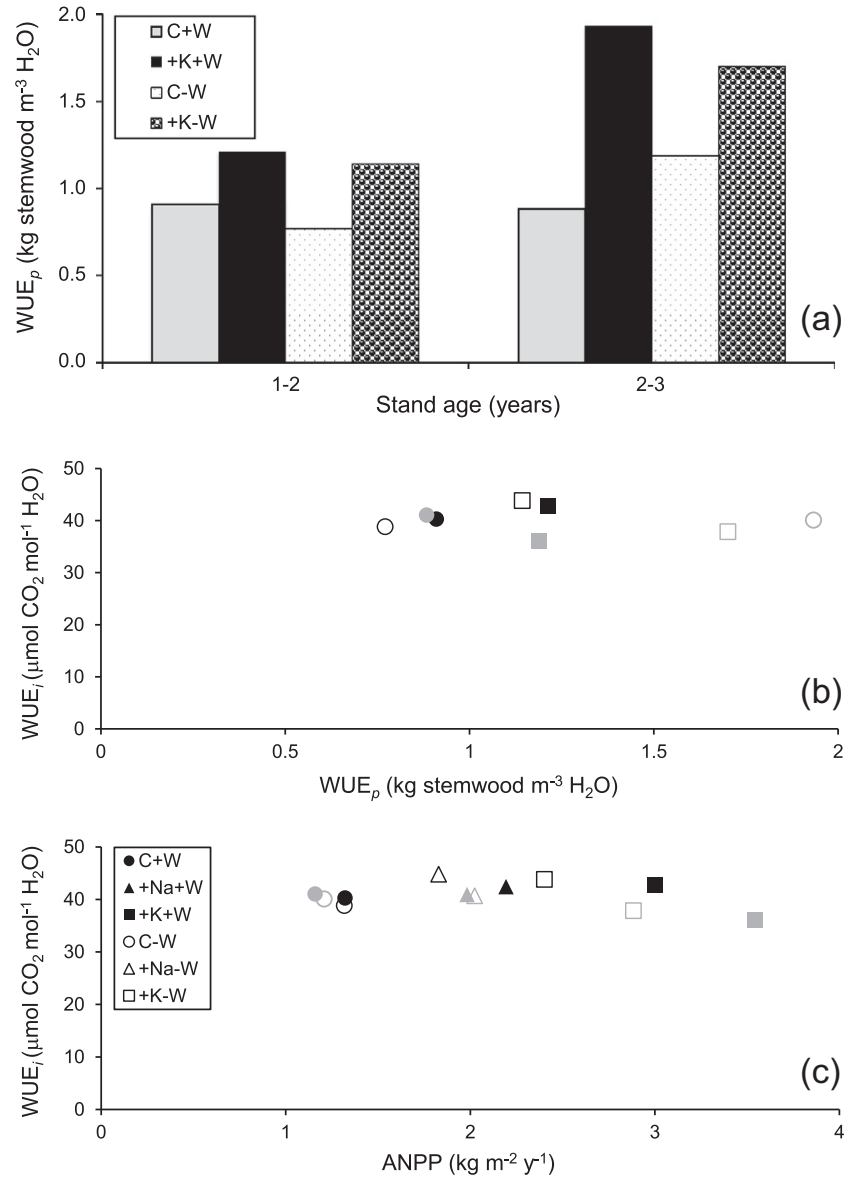

Fig. 3. Water-use efficiency for stemwood production WUE $_{p}$, ratio of stemwood biomass accumulation to stand water use) in the second and the third years after planting the Eucalyptus grandis trees (a), relationship between mean intrinsic midday water-use efficiency (WUE $\mathrm{W}_{i}$, ratio of instantaneous net $\mathrm{CO}_{2}$ assimilation rate to stomatal conductance) and water-use efficiency for stemwood production $\left(\mathrm{WUE}_{p}\right)(\mathrm{b})$ and between mean intrinsic water-use efficiency (WUE $\mathrm{W}_{i}$ and aboveground net primary productivity (ANPP) (c), in the second (black symbols) and third (gray symbols) year after planting the Eucalyptus grandis trees. $\mathrm{C},+\mathrm{Na}$ and $+\mathrm{K}$ refer to the Control, Na-fertilized and K-fertilized plots, respectively. $+\mathrm{W}$ and $-\mathrm{W}$ refer to undisturbed rainfall and exclusion of $37 \%$ of throughfall, respectively. WUE for stemwood production was not estimated in $+\mathrm{Na}+\mathrm{W}$ and $+\mathrm{Na}-\mathrm{W}$ because the sap flow was not measured.

affected. Fertilization had little effect on $A$ and $g_{s}$ during the dry season but reduced $\mathrm{WUE}_{i}$. WUE $\mathrm{W}_{i}$ remained steady during the day on all the measurement dates, except during the driest period (end of the 2012 dry season) where $\mathrm{WUE}_{i}$ at midday was low in the most water-deficient treatments $(+\mathrm{Na}-\mathrm{W}$ and $+\mathrm{K}-\mathrm{W})$ and high 

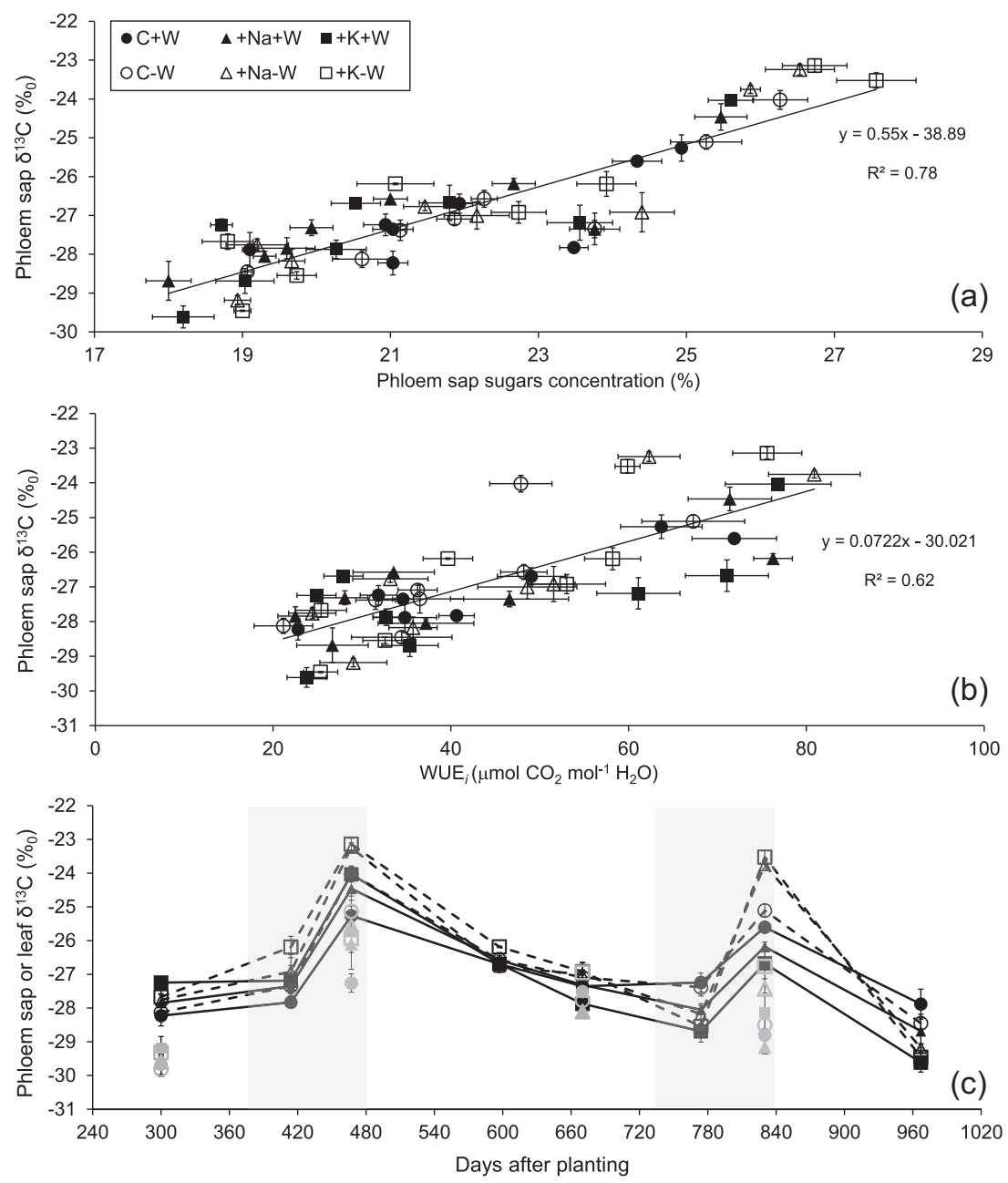

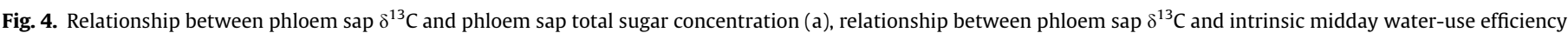

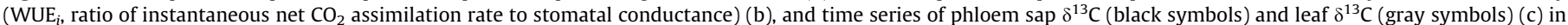

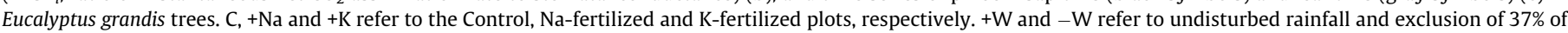
throughfall, respectively. Vertical and horizontal bars indicate standard errors between blocks $(n=3)$. The shaded areas represent the dry season (July-September).

in the other treatments. Both $\mathrm{WUE}_{i}$ values and the diurnal range of $W_{U E}$ were higher during the dry seasons than during the rainy seasons, for all treatments.

\subsection{Seasonal variations of predawn leaf water potential and midday $W U E_{i}$}

Midday $\mathrm{WUE}_{i}$ depended strongly on the season with a sharp increase during dry periods (Fig. 6a). There was a strong correlation between $A$ and $g_{\mathrm{s}}$ for all measurements $\left(R^{2}=0.89\right)$ showing that the midday $\mathrm{WUE}_{i}$ was not affected by the water supply and fertilization regimes (Fig. 6b). The midday $\mathrm{WUE}_{i}$ as well as the slope of the correlation between $A$ and $g_{\mathrm{s}}\left(\mathrm{d} A / \mathrm{d} g_{\mathrm{s}}\right)$ decreased rapidly with increasing $g_{s}$. WUE $E_{i}$ was strongly correlated to predawn leaf water potential (Fig. 7a) as well as VPD (Fig. 7b), irrespective of the water supply and fertilization regimes.

\section{Discussion}

\subsection{Effects of fertilization and throughfall exclusion on tree growth}

$\mathrm{K}$, and to a lesser extent Na supply, increased stemwood production. Previous studies in this experimental setup showed that gross primary production (GPP) was also greatly increased by $\mathrm{K}$ and $\mathrm{Na}$ fertilization as a result of lower stomatal and mesophyll resistance to $\mathrm{CO}_{2}$ diffusion and higher photosynthetic capacity in the leaves (Battie-Laclau et al., 2014a), as well as an increase in total leaf area and light use efficiency (Christina et al., 2015). K fertilization has been shown to increase leaf area and ANPP in $\mathrm{K}$-deficient soils and replacing $\mathrm{K}$ by $\mathrm{Na}$ in some physiological processes, which has been studied for several decades in $C_{4}$ species (Maathuis, 2014), has been recently shown to be possible for some $\mathrm{C}_{3}$ species such as cacao (Gattward et al., 2012), eucalypts (BattieLaclau et al., 2013, 2014a) and olive trees (Erel et al., 2014). Studies have also demonstrated increases in sugar maple crown vigor and growth in response to cation fertilization (Moore and Ouimet, 2006; Bal et al., 2015).

Throughfall exclusion reduced the beneficial effect of $\mathrm{K}$ fertilization on the aboveground net primary production. E. grandis trees cope with drought by reducing their total leaf area (Whitehead and Beadle, 2004; le Maire et al., 2011), which reduces light absorption and consequently whole tree carbon assimilation (Christina et al., 2015). K-fertilized trees were more affected by drought than K-deficient trees with lower LAI and $g_{s}$, values and consequently lower tree growth rates and lower water demand than K-fertilized trees (Battie-Laclau et al., 2014b). Increased growth of $E$. globulus trees in response to $\mathrm{N}$ fertilization was also associated with an increase in water stress during dry periods 

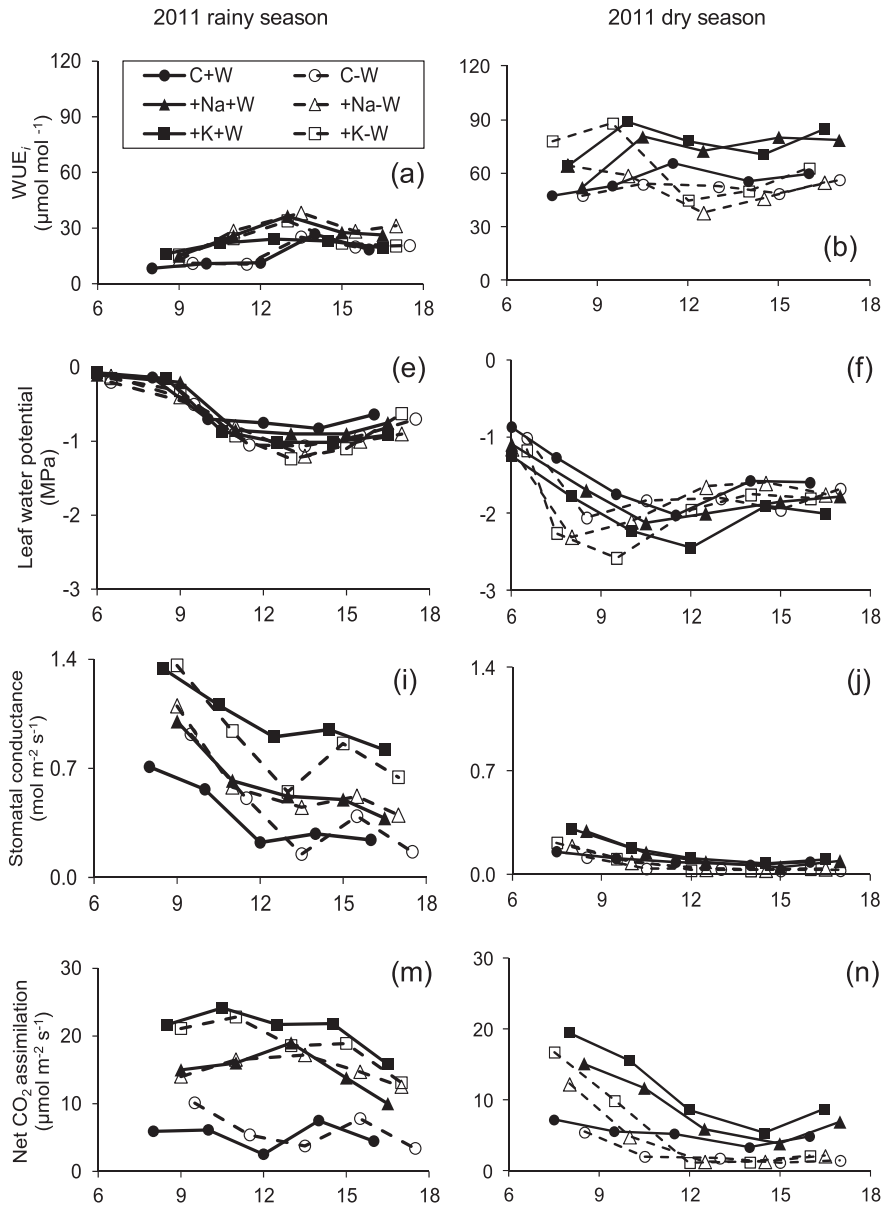

2012 dry season
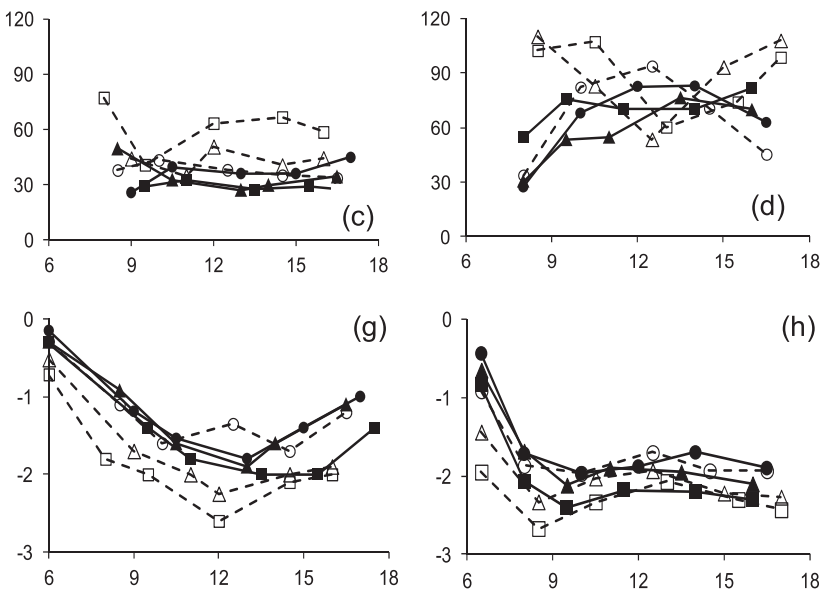

(h)
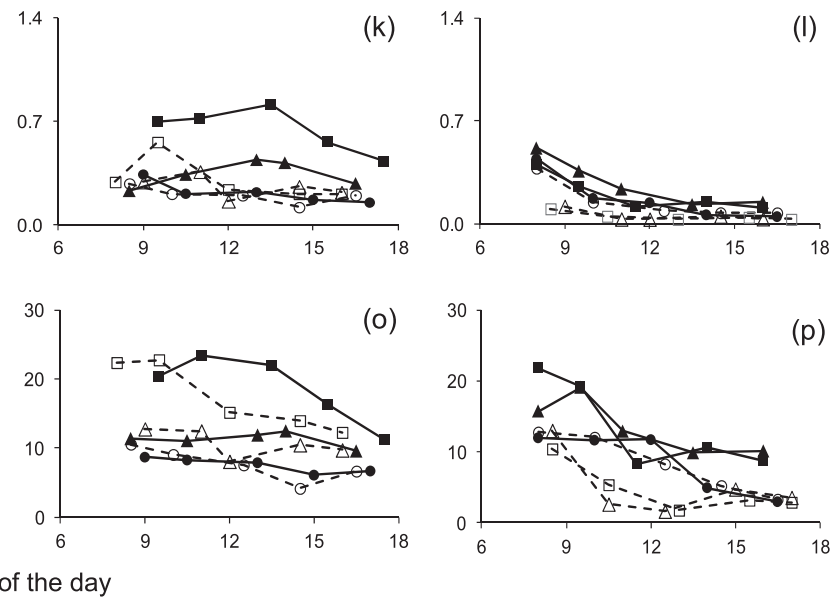

(o)

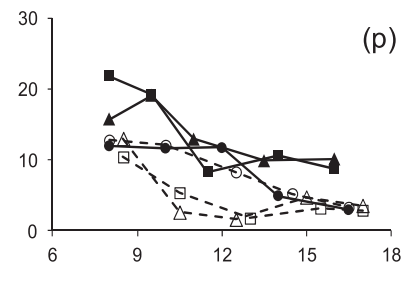

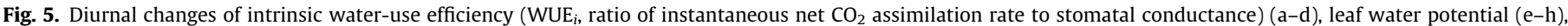

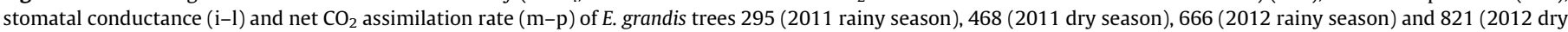

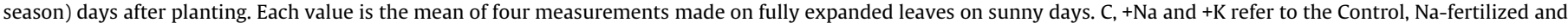
K-fertilized plots, respectively. +W and -W refer to undisturbed rainfall and exclusion of $37 \%$ of throughfall, respectively.

(White et al., 2009b, 2014). Strong positive correlations between biomass production, tree water requirements and soil water availability are well documented (Brando et al., 2008; Muller et al., 2011; Lemoine et al., 2013). Consequently, supplying nutrients to maximize tree growth may increase tree water requirements and lead to water shortage in severe drought. In this experiment, the effect of throughfall exclusion on wood production in the first two years of the experiment might have been reduced as fine roots were able to access large quantities of water stored in deep soil layers (Christina et al., 2011; Laclau et al., 2013). However, deep soil water stocks rapidly decreased in the $+\mathrm{K}$ plots as the stand aged (Battie-Laclau et al., 2014b), affecting tree growth in the third year after planting.

In addition to a direct effect of fertilization regimes on physiological mechanisms that are dependent on $\mathrm{K}$ and $\mathrm{Na}$, instant leaf photosynthesis might also be indirectly influenced by $\mathrm{N}$ and $\mathrm{P}$ nutrition. However, $\mathrm{N}$ and $\mathrm{P}$ concentrations in fully expanded young leaves were lower in $+\mathrm{K}-\mathrm{W}$ plots than in the other treatments at most of the sampling dates (data not shown), whereas instant leaf photosynthesis was much higher in $+\mathrm{K}-\mathrm{W}$ than in $\mathrm{C}$ plots (Battie-Laclau et al., 2014b), which suggests that soil $\mathrm{N}$ and $P$ availability was adequate in all the treatments. The amounts of $\mathrm{N}$ and $\mathrm{P}$ applied were similar in all the treatments and the high ANPP values for the third year after planting in $+\mathrm{K}+\mathrm{W}$ plots compared to other eucalypt plantations in Brazil (Ryan et al., 2010) confirm that soil $\mathrm{N}$ and $\mathrm{P}$ availability was not limiting for tree growth in this experiment (Gonçalves et al., 2008; Laclau et al. 2009).

\subsection{Mechanisms accounting for an increase in WUE for stemwood production in response to $K$ fertilization}

The study partially confirmed our first hypothesis. The various treatments affected WUE for stemwood production through changes in allocation patterns but short-term leaf-level WUE was not affected. The strong effect of $\mathrm{K}$ fertilization on WUE for stemwood production resulted from a greater increase in wood production than in water use. The lack of correlation between annual values of WUE for stemwood production and $\mathrm{WUE}_{i}$ indicates that most of the variability in WUE for stemwood production comes from mechanisms occurring after the phase of leaf gas exchange. There are at least three reasons for the lack of a connection between short-term leaf-level $\mathrm{WUE}_{i}$ and annual WUE for stemwood production: (1) maintenance of a fairly constant intercellular $\mathrm{CO}_{2}$ concentration (and little difference in photosynthesis/stomatal conductance over most of the operating range), (2) large differences in leaf area between the control and $+\mathrm{K}$ or $+\mathrm{Na}$ treatments giving them a much higher canopy photosynthesis, and (3) changes in the partitioning of canopy photosynthesis between wood and other tree components. There 

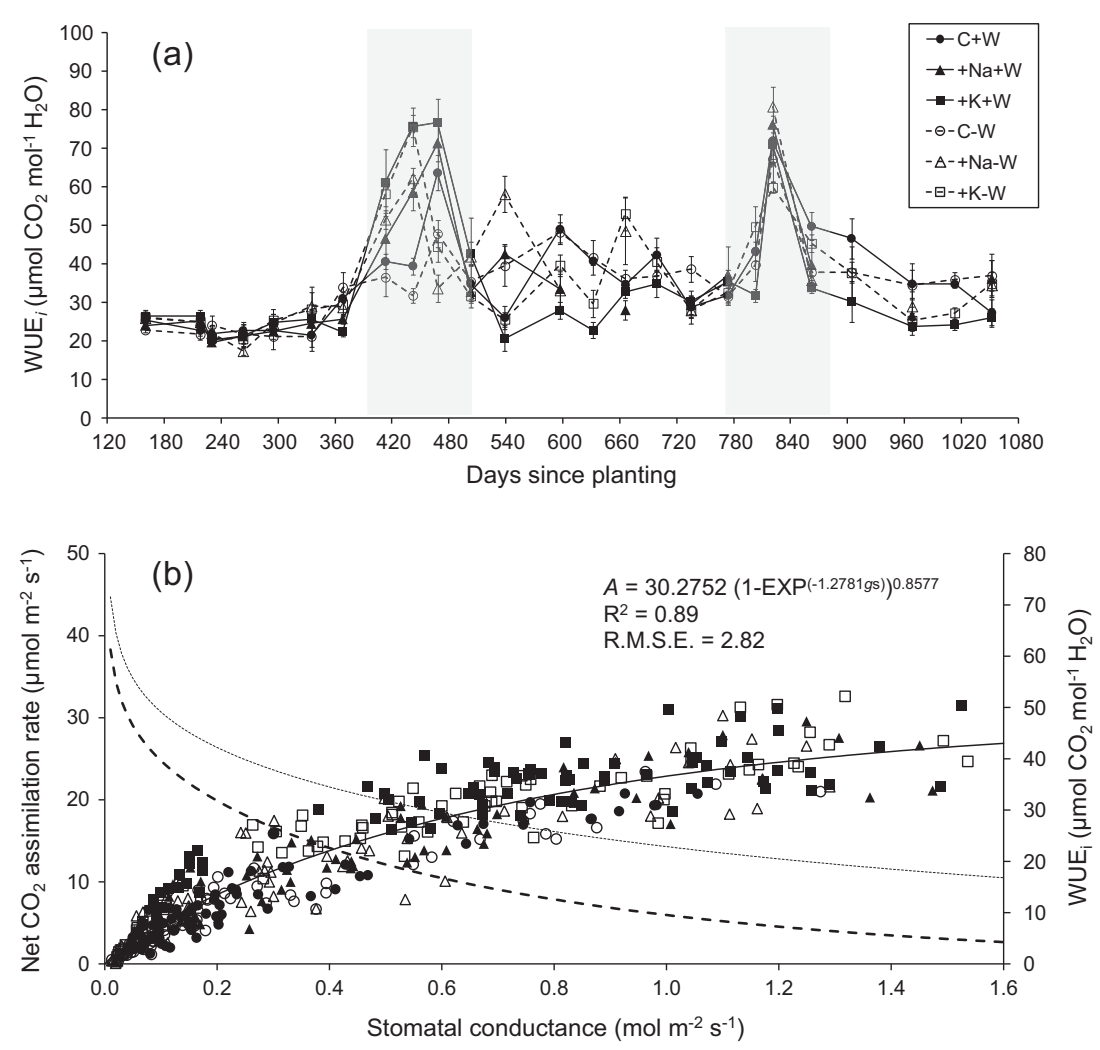

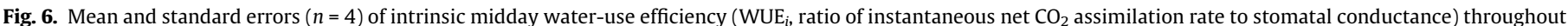

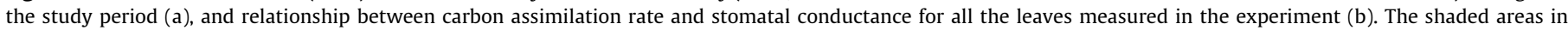

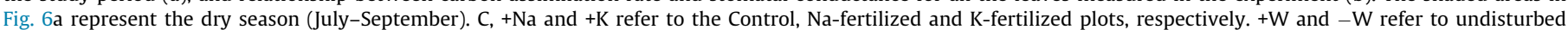

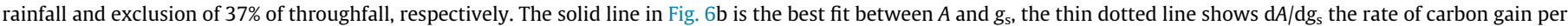
unit increase in stomatal conductance, and the thick dotted line shows $A / g_{\mathrm{s}}\left(\mathrm{WUE}_{i}, \mu \mathrm{mol} \mathrm{mol}{ }^{-1}\right)$.

was a significant increase in the fraction of ANPP allocated to wood production in response to fertilization. Leaf longevity is about twice as high in K-fertilized than in K-deficient E. grandis trees whereas the total leaf production does not change, leading to much higher LAI and ANPP values in K-fertilized trees (Laclau et al., 2009; Epron et al., 2012). The lower proportion of ANPP flowing to foliage production in K-fertilized than in $\mathrm{K}$ deficient trees helps to increase GPP partitioning to wood NPP. An adjacent experiment at the study site showed that $\mathrm{K}$ and $\mathrm{Na}$ fertilization decreases the proportion of GPP allocated belowground in E. grandis plantations (Epron et al., 2012). Total belowground carbon fluxes (the sum of root production, root respiration, and mycorrhizal production and respiration) from 4 to 6 years after planting accounted for $31 \%$ of GPP in K-deficient trees and only $21-23 \%$ in K- and Na-fertilized trees. $\mathrm{K}$ and $\mathrm{Na}$ fertilization significantly increased the fraction of GPP allocated to stemwood NPP in this experiment. There is growing evidence that management practices that increase GPP in eucalypt plantations also increase the fraction of GPP allocated to wood NPP by decreasing the fraction of GPP allocated belowground. This pattern was also shown in response to fertilization (NPK and micronutrients) in Eucalyptus saligna plantations in Hawaï (Giardina et al., 2003), as well as in response to irrigation in clonal Eucalyptus plantations at four sites in Brazil (Ryan et al., 2010). Similarly, the fraction of GPP allocated to stem NPP increased across a gradient of productivity in a commercial E. grandis plantation in Brazil (Campoe et al., 2012). WUE for stemwood production in our study ranged from 1.1 to $1.9 \mathrm{~kg}$ of stemwood $\mathrm{m}^{-3}$ of transpired water for K-fertilized trees, which is consistent with other estimates in eucalypt plantations (Stape et al., 2004).

\subsection{Effects of water and nutrient supply regimes on $W U E_{i}$ and on $\delta^{13} C$}

In agreement with our second hypothesis, phloem $\delta^{13} \mathrm{C}$ values as well as sugar concentrations in phloem sap (and to a lesser extent leaf $\delta^{13} \mathrm{C}$ ) were good predictors of $\mathrm{WUE}_{i}$. E. grandis trees responded to water shortage during dry periods by increasing the leaf WUE (i.e. high midday $W^{\prime} E_{i}$ ) and crown WUE (i.e. the phloem $\delta^{13} \mathrm{C}$ values which integrate the diurnal variations of $\mathrm{WUE}_{i}$ within the crown were less negative). The moderate variability in $W_{U E}$ throughout the day (except during the driest period that occurred for only a few days during the 3 years of the study) shows that midday $\mathrm{WUE}_{i}$ can be considered to be a reasonable proxy of daily $\mathrm{WUE}_{i}$, contrary to poplar genotypes in a pot experiment (Rasheed et al., 2013, 2015). Instant leaf net $\mathrm{CO}_{2}$ assimilation rate $(A)$ was close to maximum values at midday during the rainy season, showing that midday measurements represent a substantial amount of the daily photosynthesis and, therefore, that phloem $\delta^{13} \mathrm{C}$ values should be well correlated to $\mathrm{WUE}_{i}$ measurements at midday. Although low $A$ values at midday during the dry season indicate that phloem $\delta^{13} \mathrm{C}$ values were mainly influenced by $A$ in the morning, the generally stable diurnal patterns of $\mathrm{WUE}_{i}$ suggest that phloem $\delta^{13} \mathrm{C}$ should be well correlated with midday $\mathrm{WUE}_{i}$. The increase in $W_{U E}$ during dry periods was attributed to a stronger decrease in stomatal conductance $\left(g_{s}\right)$ than in $A$ in $E$. grandis leaves (Battie-Laclau et al., 2014a,b). This pattern is well documented for grasslands (Niu et al., 2011) and woody species (Bauerle et al., 2006; Nagakura et al., 2004; Battipaglia et al., 2013; Lévesque et al., 2014). However, excluding $\sim 450 \mathrm{~mm} \mathrm{y}^{-1}$ of throughfall was insufficient to increase the mean $\mathrm{WUE}_{i}$ over the first three years after planting. 

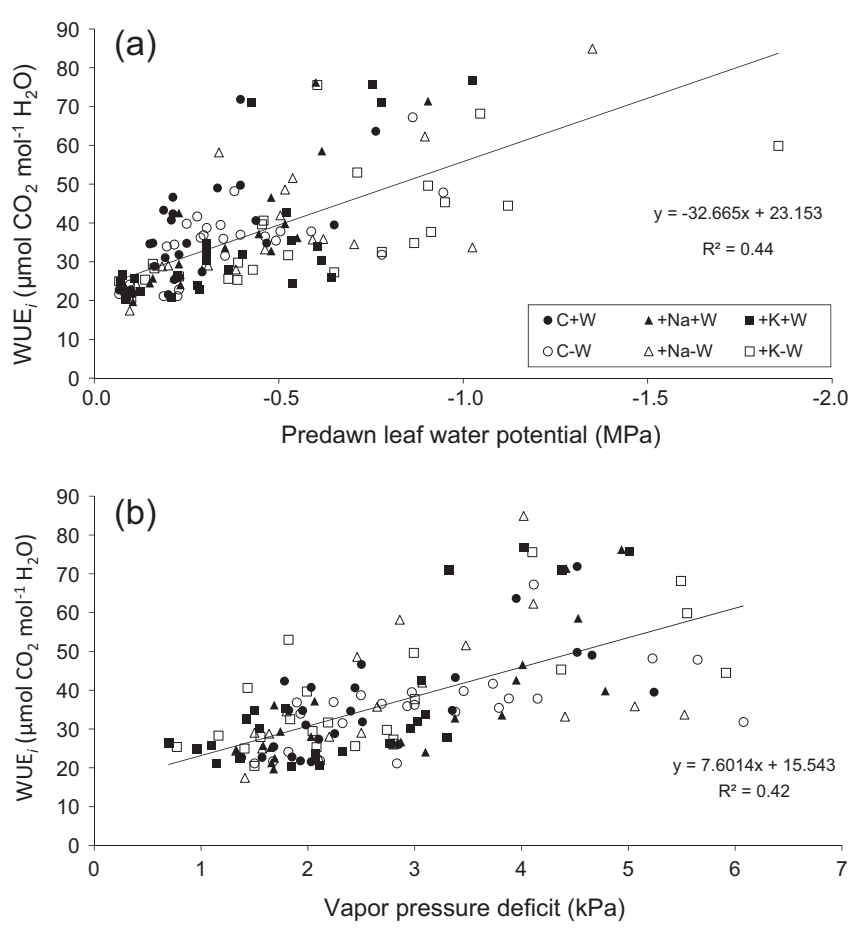

Fig. 7. Relationships between intrinsic midday water-use efficiency (WUE $E_{i}$, ratio of instantaneous net $\mathrm{CO}_{2}$ assimilation rate to stomatal conductance) and predawn leaf water potential (a) and vapor pressure deficit in the air (b). $\mathrm{C},+\mathrm{Na}$ and $+\mathrm{K}$ refer to the Control, Na-fertilized and K-fertilized plots, respectively. $+\mathrm{W}$ and $-\mathrm{W}$ refer to undisturbed rainfall and exclusion of $37 \%$ of throughfall, respectively.

$\mathrm{WUE}_{i}$ was little affected by the $\mathrm{K}$ and $\mathrm{Na}$ fertilization regimes over the study period. A preliminary study in this experiment showed that leaf anatomy, $A, g_{s}$, and mesophyll conductance were strongly affected by K fertilization, and to a lesser extent by Na fertilization (Battie-Laclau et al., 2014a). However, relative limitations of $A$ caused by $g_{s}$, mesophyll conductance, and biochemical photosynthetic capacity (maximum rates of carboxylation and electron transport) were not influenced by $\mathrm{K}$ and $\mathrm{Na}$ fertilization in this study on E. grandis trees, unlike the response of Robinia pseudoacacia seedlings to N supply (Liu et al., 2013). This may explain why the relationship between $A$ and $g_{s}$ was similar for all treatments and thus the weak influence of $\mathrm{K}$ and $\mathrm{Na}$ fertilization on $\mathrm{WUE}_{i}$. A meta-analysis showed that $\mathrm{WUE}_{i}$ is systematically correlated with $V_{\mathrm{cmax}} / g_{\mathrm{s}}$ and $g_{\mathrm{m}} / g_{\mathrm{s}}$ ratios across species, habitats, and environmental conditions (Gago et al., 2014). For eucalypts and some other tree species, coordination between $g_{s}$ and photosynthetic capacity (Cernusak et al., 2011) or the adjustment of the ratio of leaf area to water-conducting tissue (Hutley et al., 2011) were found to damp the response of the intercellular to ambient carbon dioxide concentration $\left(C_{\mathrm{i}} / C_{\mathrm{a}}\right)$ ratio and carbon isotopic discrimination to resource availability gradients (Cernusak et al., 2013). In $C_{3}$ species, the slope of the relationship between $A$ and $g_{\mathrm{s}}\left(\mathrm{d} A / \mathrm{d} g_{\mathrm{s}}\right)$ rapidly decreases with increasing $g_{s}$ at low $g_{s}$ values, but flattens at conductances above $0.4 \mathrm{~mol} \mathrm{~m}^{-2} \mathrm{~s}^{-1}$ (Hetherington and Woodward, 2003). Therefore, plants such as E. grandis trees with high stomatal conductances are expected to show lower dependence of $\mathrm{WUE}_{i}$ on conductance than species with lower stomatal conductance. $\mathrm{WUE}_{i}$ shows high variability only during short dry periods (e.g. at the end of the dry season), when $g_{s}$ decreases to values well below $0.4 \mathrm{~mol} \mathrm{~m} \mathrm{~m}^{-2} \mathrm{~s}^{-1}$. Although in this experiment $\mathrm{K}$ and $\mathrm{Na}$ fertilization did not have a significant effect on $\mathrm{WUE}_{i}$ in $E$. grandis trees, $\mathrm{K}$ and $\mathrm{Na}$ fertilization clearly increased $\mathrm{WUE}_{i}$ in cacao plants (Gattward et al., 2012) and olive trees (Erel et al., 2014). Different effects of $\mathrm{K}$ and $\mathrm{Na}$ fertilization on leaf WUE may indicate that there are significant differences between species in the response of stomatal control mechanisms and/or photosynthetic capacity to $\mathrm{K}$ and $\mathrm{Na}$ availability (Erel et al., 2014).

\subsection{Consequences for tree breeding}

The lack of correlation between WUE for stemwood production and $\mathrm{WUE}_{i}$ in our study suggests that proxies of $\mathrm{WUE}_{i}$ (e.g. leaf or phloem $\delta^{13} \mathrm{C}$ ) cannot be used to estimate WUE for stemwood production. Earlier studies also showed that an increase in $\mathrm{WUE}_{i}$ under water stress was not correlated with tree growth (Andreu et al., 2011; Battipaglia et al., 2013; Lévesque et al., 2014). In a literature review, Seibt et al. (2008) stress that WUE, WUE for stemwood production and leaf $\delta^{13} \mathrm{C}$ can vary independently as they are affected differently by changes in environmental conditions and plant properties. Contrary to $\mathrm{WUE}_{i}$, WUE for stemwood production is strongly influenced by many non-photosynthetic factors, such as the proportion of assimilated carbon lost by respiration (around $50 \%$ of GPP), allocation to symbionts, exudation, turnover, litter and by the water vapor lost independently of photosynthesis (e.g. transpiration from stems, cuticles) (Farquhar et al., 1989). Differences in allocation to compartments with rapid turnover (leaves, fine roots) and slow turnover (stemwood) and differences in respiration rates induced by the treatments may have a significant effect on WUE for stemwood production. Water stress and nutrient deficiencies generally decrease the carbon use efficiency (Giardina et al., 2003; Callister and Adams, 2006; Vicca et al., 2012; Mitchell et al., 2013; Zhang et al., 2014) and the partitioning of assimilated carbon to wood production (Keith et al., 1997; Litton et al., 2007; Ryan et al., 2010), thus reducing WUE for stemwood production.

Our results suggest that breeding programs selecting the clones with the highest growth rates in deep tropical soils tend to select the genotypes with the highest water-use efficiency for stemwood production. Large amounts of fertilizer are commonly applied in clonal tests and water is the main factor limiting tree growth in the most productive eucalypt plantations (Stape et al., 2010). A lack of deep drainage has been shown after canopy closure for highly productive eucalypt plantations growing in deep tropical soils with an annual rainfall of approx. $1500 \mathrm{~mm}$ (e.g. Laclau et al., 2013). This pattern suugests that all the clones can use approximately the same amount of water (stored in the soil after clear cutting + rainfall from planting to harvesting) and that the clones with the highest biomass production in clonal tests are, therefore, those with the highest WUE for stemwood production. There is growing evidence that resource use efficiency for stem biomass production is positively correlated with tree growth rates in tropical eucalypt plantations, via changes in allocation patterns. Changes in light use efficiency (Binkley et al., 2010; Campoe et al., 2013), water use efficiency and nitrogen use efficiency along forest production gradients (Binkley et al., 2004), suggest that intensive management practices increasing the productivity of eucalypt plantations could reduce the resources required to produce a given quantity of wood. However, the most productive trees also have the highest transpiration rates, which might increase the risk of hydraulic failure under conditions of extreme water deficit (White et al., 2009b; Battie-Laclau et al., 2014b). Increasing WUE for biomass production might, therefore, not be a relevant criterion for breeding programs in regions where there is a major risk of tree mortality during drought.

\section{Conclusion}

While different fertilization and water supply regimes had little effect on intrinsic WUE, favorable growing conditions clearly increased WUE for stemwood production. Allocation patterns in 
response to nutrient and water supply appeared to be a major driver of WUE for stemwood production. Consequently, leaf and phloem $\delta^{13} \mathrm{C}$, which are common proxies of WUE at leaf level, were unable to predict large changes in WUE for stemwood production of our E. grandis clone. These results contribute to improving our understanding of the mechanisms governing the response of WUE to changes in nutrient and water availability. They also may be helpful for taking account of nutrient limitations in process-based models and for identifying the most relevant traits for breeding strategies in a context of climate change.

\section{Acknowledgments}

We should like to thank the staff at the Itatinga Experimental Station (ESALQ-USP), in particular Rildo Moreira e Moreira (Esalq, USP), as well as Eder Araújo da Silva and FLORAGRO (www.floragroapoio.com.br) for their technical support. We acknowledge the CENA laboratory (USP, Piracicaba, Brazil) and the BPMP laboratory (INRA, Montpellier, France) for the $\delta^{13} \mathrm{C}$ analyses. The study was funded by FAPESP (www.fapesp.br, 2010/50663-8), CIRAD, USP-COFECUB (Project 2011-25), AGREENIUM (Plantrotem project), SOERE F-ORE-T, and the Agence Nationale de la Recherche (Maccac project, AGROBIOSPHERE program, Innovkar project).

\section{Appendix A. Supplementary material}

Supplementary data associated with this article can be found, in the online version, at http://dx.doi.org/10.1016/j.foreco.2016.01. 004.

\section{References}

Ainsworth, E.A., Long, S.P., 2005. What have we learned from 15 years of free-air $\mathrm{CO}_{2}$ enrichment (FACE)? A meta-analytic review of the responses of photosynthesis, canopy properties and plant production to rising $\mathrm{CO}_{2}$. New Phytol. 165 (2), 351-372.

Albaugh, J.M., Dye, P.J., King, J.S., 2013. Eucalyptus and water use in South Africa. Int J. Forest. Res., 11 p 852540

Allen, C.D., Macalady, A., Chenchouni, H., Bachelet, D., McDowell, N., Vennetier, M. Gonzales, P., Hogg, T., Rigling, A., Breshears, D., et al., 2010. A global overview of drought and heat-induced tree mortality reveals emerging climate change risks for forests. For. Ecol. Manage. 259, 660-684.

Allen, R., Pereira, L., Raes, D., Smith, M., 1998. Crop Evapotranspiration. Guidelines for Computing Crop Water Requirements. FAO Irrigation and Drainage Paper 56. <http://www.fao.org/docrep/X0490E/X0490E00.htm>, 301pp.

Almeida, J.C.R., Laclau, J.P. Gonçalves, J.L.M., Ranger, J. Saint-André, L., 2010. A positive growth response to $\mathrm{NaCl}$ applications in Eucalyptus plantations established on K-deficient soils. For. Ecol. Manage. 259, 1786-1795.

Andreu, L., Planells, O., Gutierrez, E., Muntan, E., Helle, G., Anchukaitis, K.J., Schleser, G.H., 2011. Long tree-ring chronologies reveal 20th century increases in wateruse efficiency but no enhancement of tree growth at five Iberian pine forests. Global Change Biol. 17, 2095-2112.

Bal, T.L., Storer, A.J., Jurgensen, M.F., Doskey, P.V., Amacher, M.C., 2015. Nutrient stress predisposes and contributes to sugar maple dieback across its northern range: a review. Forestry $88,64-83$.

Battie-Laclau, P., Laclau, J.-P., Piccolo, M.C., Arenque, B.C., Beri, C., Mietton, L., Muniz, M.R.A., Jordan-Meille, L., Buckeridge, M.S., Nouvellon, Y., et al., 2013. Influence of potassium and sodium nutrition on leaf area components in Eucalyptus grandis trees. Plant Soil 371, 19-35.

Battie-Laclau, P., Laclau, J.-P., Beri, C., Mietton, L., Muniz, M.A., Arenque, B.C., Piccolo, M.C., Jordan-Meille, L., Bouillet, J.-P., Nouvellon, Y., 2014a. Photosynthetic and anatomical responses of Eucalyptus grandis leaves to potassium and sodium supply in a field experiment. Plant, Cell Environ. 37, 70-81.

Battie-Laclau, P., Laclau, J.-P., Domec, J.-C., Christina, M., Bouillet, J.-P., de Cassia Piccolo, M., Gonçalves, J.L. de M., Moreira, R.M., Krusche, A.V., Nouvellon, Y., 2014b. Effects of potassium and sodium supply on drought-adaptive mechanisms in Eucalyptus grandis plantations: implications under a drier future climate. New Phytol. 203 (2), 401-413.

Battipaglia, G., Saurer, M., Cherubini, P., Calfapietra, C., McCarthy, H.R., Norby, R.J. Cotrufo, MF. 2013. Elevated $\mathrm{CO}_{2}$ increases tree-level intrinsic water use efficiency: insights from carbon and oxygen isotope analyses in tree rings across three forest FACE sites. New Phytol. 197 (2), 544-554.

Bauerle, W.L., Wang, G.G., Bowden, J.D., Hong, C.M., 2006. An analysis of ecophysiological responses to drought in American Chestnut. Ann. For. Sci. 63, 833-842.
Beer, C., Ciais, P., Reichstein, M., Baldocchi, D., Law, B.E., Papale, D., Soussana, J.-F., Ammann, C., Buchmann, N., Franket, D., et al., 2009. Temporal and among-site variability of inherent water use efficiency at the ecosystem level. Global Biogeochem. Cycles 23, GB2018.

Binkley, D., Stape, J.L., Ryan, M.G., 2004. Thinking about efficiency of resource use in forests. For. Ecol. Manage. 193 (1-2), 5-16.

Binkley, D., Stape, J.L., Bauerle, W.L., Ryan, M.G., 2010. Explaining growth of individual trees: light interception and efficiency of light use by Eucalyptus at four sites in Brazil. For. Ecol. Manage. 259, 1704-1713.

Brando, P.M., Nepstad, D.C., Davidson, E.A., Trumbore, S.E., Ray, D., Camargo, P., 2008. Drought effects on litterfall, wood production and belowground carbon cycling in an Amazon forest: results of a throughfall reduction experiment. Philos. Trans. Roy. Soc. B 363, 1839-1848.

Bréda, N., Huc, R., Granier, A., Dreyer, E., 2006. Temperate forest trees and stands under severe drought: a review of ecophysiological responses, adaptation processes and long-term consequences. Ann. For. Sci. 63, 625-644.

Cakmak, I., 2005. The role of potassium in alleviating detrimental effects of abiotic stresses in plants. J. Plant Nutr. Soil Sci. 168, 521-530.

Callister, A.N., Adams, M.A., 2006. Water stress impacts on respiratory rate, efficiency and substrates, in growing and mature foliage of Eucalyptus spp. Planta 224, 680-691.

Campoe, O.C., Stape, J.L., Laclau, J.-P., Marsden, C., Nouvellon, Y., 2012. Stand-level patterns of carbon fluxes and partitioning in a Eucalyptus grandis plantation across a gradient of productivity, in São Paulo state, Brazil. Tree Physiol. 32, 696-706.

Campoe, O.C., Stape, J.L., Nouvellon, Y., Laclau, J.-P., Bauerle, W.L., Binkley, D., Le Maire, G., 2013. Stem production, light absorption and light use efficiency between dominant and non-dominant trees of Eucalyptus grandis across a productivity gradient in Brazil. For. Ecol. Manage. 288, 14-20.

Cernusak, L.A., Arthur, D.J., Pate, J.S., Farquhar, G.D., 2003. Water relations link carbon and oxygen isotope discrimination to phloem sap sugar concentration in Eucalyptus globulus. Plant Physiol. 131, 1544-1554.

Cernusak, L.A., Aranda, J., Marshall, J.D., Winter, K., 2007. Large variation in wholeplant water-use efficiency among tropical tree species. New Phytol. 173, 294305

Cernusak, L.A., Hutley, L.B., Beringer, J., Holtum, J.A.M., Turner, B.L., 2011 Photosynthetic physiology of eucalypts along a sub-continental rainfall gradient in northern Australia. Agric. For. Meteorol. 151, 1462-1470.

Cernusak, L.A., Ubierna, N., Winter, K., Holtum, J.A.M., Marshall, J.D., Farquhar, G.D., 2013. Environmental and physiological determinants of carbon isotope discrimination in terrestrial plants. New Phytol. 200, 950-965.

Christina, M., Laclau, J.-P., Gonçalves, J.L.M., Jourdan, C., Nouvellon, Y., Bouillet, J.-P., 2011. Almost symmetrical vertical growth rates above and below ground in one of the world's most productive forests. Ecosphere 2, art 27.

Christina, M., Le Maire, G., Battie-Laclau, P., Bouillet, J.-P., Nouvellon, Y., Jourdan, C., Gonçalves, J.L.M., Laclau, J.-P., 2015. Measured and modeled interactive effects of potassium and water deficiencies on photosynthesis and light use efficiency in Eucalyptus grandis plantations. Global Change Biol. 21, 2022-2039.

da Costa, A.C.L., Galbraith, D., Almeida, S., Portella, B.T.T., da Costa, M., de Athaydes Silva Junior, J., Braga, A.P., de Gonçalves, P.H.L., de Oliveira, A.A.R., Fisher, R., et al., 2010. Effect of $7 \mathrm{yr}$ of experimental drought on vegetation dynamics and biomass storage of an eastern Amazonian rainforest. New Phytol. 187, 579-591.

Delgado-Rojas, J.S., Laclau, J.-P., Roupsard, O., Stape, J.L., Ranger, J., Bouillet, J.-P., Nouvellon, Y., 2010. Calibration of home-made heat dissipation probes for a full rotation of Eucalyptus grandis trees in Brazil. AGU, ID 972492.

Dvorak, W.S., 2012. Water use in plantations of eucalypts and pines: a discussion paper from a tree breeding perspective. Int. Forest. Rev. 14, 110-119.

Epron, D., Laclau, J.-P., Almeida, J.C.R., Gonçalves, J.L.M., Ponton, S., Sette, C.R.J.R., Delgado-Rojas, J.S., Bouillet, J.-P., Nouvellon, Y., 2012. Do changes in carbon allocation account for the growth response to potassium and sodium applications in tropical Eucalyptus plantations? Tree Physiol. 31, 1-13.

Erel, R., Ben-Gal, A., Dag, A., Schwartz, A., Yermiyahu, U., 2014. Sodium replacement of potassium in physiological processes of olive trees (var. Barnea) as affected by drought. Tree Physiol. 34, 1102-1117.

Erel, R., Yermiyahu, U., Ben-Gal, A., Dag, A., Shapira, O., Schwartz, A., 2015. Modification of non-stomatal limitation and photoprotection due to $\mathrm{K}$ and $\mathrm{Na}$ nutrition of olive trees. J. Plant Physiol. 177, 1-10.

Farquhar, G.D., Richards, R.A., 1984. Isotopic composition of plant carbon correlates with water-use efficiency of wheat genotypes. Aust. J. Plant Physiol. 11 (6), 539552.

Farquhar, G.D., Ehleringer, J.R., Hubick, T., 1989. Carbon isotope discrimination and photosynthesis. Annu. Rev. Plant Physiol. Plant Mol. Biol. 40, 503-537.

Food and Agriculture Organization of the United Nations, 2014. State of the World's Forests 2014. FAO, Rome, Italy.

Franklin, O., Johansson, J., Dewar, R.C., Dieckmann, U., McMurtrie, R.E., Brännström, A., Dybzinsk, R., 2012. Modeling carbon allocation in trees: a search for principles. Tree Physiol. 32, 648-666.

Gago, J., Douthe, C., Florez-Sarasa, I., Escalona, J.M., Galmes, J., Fernie, A.R., Flexas, J., Medrano, H., 2014. Opportunities for improving leaf water use efficiency under climate change conditions. Plant Sci. 226, 108-119.

Gattward, J.N., Almeida, A.A.F., Souza Jr., J.O., Gomes, F.P., Kronzucker, H.J., 2012. Sodium-potassium synergism in Theobroma cacao: stimulation of photosynthesis, water-use efficiency and mineral nutrition. Physiol. Plant. $146,350-362$ 
Giardina, C.P., Ryan, M.G., Binkley, D., Fownes, J.H., 2003. Primary production and carbon allocation in relation to nutrient supply in a tropical experimental forest. Global Change Biol. 9, 1438-1450.

Gonçalves, J.L.M., Stape, J.L., Laclau, J.-P., Bouillet, J.-P., Ranger, J., 2008. Assessing the effects of early silvicultural management on long-term site productivity of fastgrowing eucalypt plantations: the Brazilian experience. Southern Forests 70, 105-118.

Granier, A., 1985. Une nouvelle méthode pour la mesure du flux de sève brute dans le tronc des arbres. Ann. For. Sci. 42, 81-88.

Hanson, P.J., Todd Jr., D.E., Amthor, J.S., 2001. A six-year study of sapling and largetree growth and mortality responses to natural and induced variability in precipitation and throughfall. Tree Physiol. 21, 345-358.

Harwood, C., 2011. New introductions - doing it right. In: Walker (Ed.), Developing a Eucalypt Resource. Learning from Australia and Elsewhere. Wood Technology Research Centre, University of Canterbury, Christchurch, New Zealand, pp. 125136.

Hawkins, E., Sutton, R., 2012. Time of emergence of climate signals. Geophys. Res. Lett. 39, L01702.

Hetherington, A.M., Woodward, F.I., 2003. The role of stomata in sensing and driving environmental change. Nature 424, 901-908.

Hsiao, T.C., 1973. Plant responses to water stress. Annu. Rev. Plant Physiol. 24, 519570 .

Hutley, L.B., Beringer, J., Isaac, P.R., Hacker, J.M., Cernusak, L.A., 2011. A subcontinental scale living laboratory: spatial patterns of savanna vegetation over a rainfall gradient in northern Australia. Agric. For. Meteorol. 151, 1417-1428.

IPCC, 2013. In: Stocker, T.F., Qin, D., Plattner, G.-K., Tignor, M.M.B., Allen, S.K., Boschung, J., Nauels, A., Xia, Y., Bex, V., Midgley, P.M. (Eds.), Climate Change 2013: The Physical Science Basis. Contribution of Working Group I to the Fifth Assessment Report of the Intergovernmental Panel on Climate Change. Cambridge University Press, Cambridge, UK \& New York, NY, USA.

Keitel, C., Adams, M.A., Holst, T., Matzarakis, A., Mayer, H., Rennenberg, H., Gessler, A., 2003. Carbon and oxygen isotope composition of organic compounds in the phloem sap provides a short-term measure for stomatal conductance of European beech (Fagus sylvatica L.). Plant, Cell Environ. 26, 1157-1168.

Keitel, C., Matzarakis, A., Rennenberg, H., Gessler, A., 2006. Carbon isotopic composition and oxygen isotopic enrichment in phloem and total leaf organic matter of European beech (Fagus sylvatica L.) along a climate gradient. Plant, Cell Environ. 29, 1492-1507.

Keith, H., Jacobsen, K.L., Raison, R.J., 1997. Effects of soils phosphorus availability, temperature and moisture on soil respiration in Eucalyptus pauciflora forest. Plant Soil 190, 127-141.

King, J.S., Ceulemans, R., Albaugh, J.M., Dillen, S.Y., Domec, J.-C., Fichot, R., Fischer, M., Leggett, Z., Sucre, E., Trnka, M., et al., 2013. The challenge of lignocellulosic bioenergy in a water-limited world. Bioscience 63, 102-117.

Kronzucker, H.J., Coskun, D., Schulze, J.M., Wong, J.R., Britto, D.T., 2013. Sodium as nutrient and toxicant. Plant Soil 369, 1-23.

Kunert, N., Schwendenmann, L., Potvin, C., Hölscher, D., 2012. Tree diversity enhances tree transpiration in a Panamanian forest plantation. J. Appl. Ecol. 49, $135-144$.

Laclau, J.-P., Almeida, J.C.R., Gonçalves, J.L.M., Saint-André, L., Ventura, M., Ranger, J., Moreira, R.M., Nouvellon, Y., 2009. Influence of nitrogen and potassium fertilization on leaf lifespan and allocation of above-ground growth in Eucalyptus plantations. Tree Physiol. 29, 111-124.

Laclau, J.-P., Ranger, J., Gonçalves, J.L.M., Maquère, V., Krusche, A.V., M’Bou, A.T., Nouvellon, Y., Saint-André, L., Bouillet, J.-P., Piccolo, M.C., et al., 2010. Biogeochemical cycles of nutrients in tropical Eucalyptus plantations: main features shown by intensive monitoring in Congo and Brazil. For. Ecol. Manage. 259, 1771-1785.

Laclau, J.-P., Silva, E.A., Lambais, G., Bernoux, M., Le Maire, G., Stape, J.L., Bouillet, J.P., Gonçalves, J.L.M., Jourdan, C., Nouvellon, Y., 2013. Dynamics of soil exploration by fine roots down to a depth of $10 \mathrm{~m}$ in Eucalyptus grandis plantations. Front. Plant Sci. 4 art 243.

Law, B.E., Falge, E., Gu, L., Baldocchi, D.D., Bakwin, P., Berbigier, P., Davis, K., Dolman, A.J., Falk, M., Fuentes, J.D., et al., 2002. Environmental controls over carbon dioxide and water vapor exchange of terrestrial vegetation. Agric. For. Meteorol. 113, 97-120.

le Maire, G., Marsden, C., Verhoef, W., Ponzoni, F.J., Lo Seen, D., Bégué, A., Stape, J.-L., Nouvellon, Y., 2011. Leaf area index estimation with MODIS reflectance time series and model inversion during full rotations of Eucalyptus plantations. Remote Sens. Environ. 115, 586-599.

Lemoine, R., La Camera, S., Atanassova, R., Dédaldéchamp, F., Allario, T., Pourtau, N., Bonnemain, J.L., Laloi, M., Coutos-Thévenot, P., Maurousset, L., et al., 2013. Source-to-sink transport of sugar and regulation by environmental factors. Front. Plant Sci. 4, 272.

Lévesque, M., Siegwolf, R., Saurer, M., Eilmann, B., Rigling, A., 2014. Increased wateruse efficiency does not lead to enhanced tree growth under xeric and mesic conditions. New Phytol. 203 (1), 94-109.

Lindroth, A., Cienciala, E., 1996. Water use efficiency of short-rotation Salix viminalis at leaf, tree and stand scales. Tree Physiol. 16, 257-262.

Litton, C.M., Giardina, C.P., 2008. Below-ground carbon flux and partitioning: global patterns and response to temperature. Funct. Ecol. 22, 941-954.

Litton, C.M., Raich, J.W., Ryan, M.G., 2007. Carbon allocation in forest ecosystems. Global Change Biol. 13, 2089-2109.

Liu, X., Fan, Y., Long, J., Wei, R., Kjelgren, R., Gong, C., Zhao, J., 2013. Effects of soil water and nitrogen availability on photosynthesis and water use efficiency of Robinia pseudoacacia seedlings. J. Environ. Sci. 25 (3), 585-595.
Maathuis, F.J.M., 2014. Sodium in plants: perception, signalling, and regulation of sodium fluxes. J. Exp. Bot. 65 (3), 849-858.

Marguerit, E., Bouffier, L., Chancerel, E., Costa, P., Lagane, F., Guehl, J.-M., Plomion, C., Brendel, O., 2014. The genetics of water-use efficiency and its relation to growth in maritime pine. J. Exp. Bot. http://dx.doi.org/10.1093/jxb/eru226 (Advance Access published July 1, 2014).

Merchant, A., Peuke, A.D., Keitel, C., Macfarlane, C., Warren, C., Adams, M.A., 2010 Phloem sap and leaf $\delta^{13} \mathrm{C}$, carbohydrates and amino acid concentrations in Eucalyptus globulus change systematically according to flooding and water deficit treatment. J. Exp. Bot. 61, 1785-1793.

Mitchell, P.J., O'Grady, A.P., Tissue, D.T., White, D.A., Ottenschlaeger, M.L., Pinkard, E. A., 2013. Drought response strategies define the relative contributions of hydraulic dysfunction and carbohydrate depletion during tree mortality. New Phytol. 197, 862-872.

Monclus, R., Dreyer, E., Villar, M., Petit, J.M., Barbaroux, C., Le Thiec, D., Bréchet, C., Brignolas, F., 2006. Impact of drought on productivity and water use efficiency in 29 genotypes of Populus deltoides $\times$ Populus nigra. New Phytol. 169, 765-777.

Moore, J.-D., Ouimet, R., 2006. Ten-year effect of dolomitic lime on the nutrition, crown vigor, and growth of sugar maple. Can. J. For. Res. 36, 1834-1841.

Muller, B., Pantin, F., Genard, M., Turc, O., Freixes, S., Piques, M., Gibon, Y., 2011. Water deficits uncouple growth from photosynthesis, increase C content, and modify the relationships between $\mathrm{C}$ and growth in sink organs. J. Exp. Bot. 62, $1715-1729$.

Munns, R., 2005. Genes and salt tolerance: bringing them together. New Phytol. $167,645-663$.

Nagakura, J., Shigenaga, H., Akama, A., Takahashi, M., 2004. Growth and transpiration of Japanese cedar (Cryptomeria japonica) and Hinoki cypress (Chamaecyparis obtusa) seedlings in response to soil water content. Tree Physiol. 24, 1203-1208.

Niu, S., Xing, X., Zhang, Z., Xia, J., Zhou, X., Song, B., Li, L., Wan, S., 2011. Water-use efficiency in response to climate change: from leaf to ecosystem in a temperate steppe. Global Change Biol. 17, 1073-1082.

Olbrich, B.W., Le Roux, D., Poulter, A.G., Bond, W.J., Stock, W.D., 1993. Variation in water use efficiency and 13C levels in Eucalyptus grandis clones. J. Hydrol. 150, 615-633.

Osmond, C.B., Bjorkman, O., Anderson, D.J., 1980. Physiological Processes in Plant Ecology: Toward a Synthesis with Atriplex. Springer-Verlag, Berlin, FRG.

Pate, P., Arthur, D., 1998. $\delta^{13} \mathrm{C}$ analysis of phloem sap carbon: novel means of evaluating seasonal water stress and interpreting carbon isotope signatures of foliage and trunk wood of Eucalyptus globulus. Oecologia 117, 301-311.

Ponton, S., Dupouey, J.-L., Bréda, N., Dreyer, E., 2002. Comparison of water-use efficiency of seedlings from two sympatric oak species: genotype $\times$ environment interactions. Tree Physiol. 22, 413-422.

Rascher, K.G., Maguas, C., Werner, C., 2010. On the use of phloem sap $\delta^{13} \mathrm{C}$ as an indicator of canopy carbon discrimination. Tree Physiol. 30, 1499-1514.

Rasheed, F., Dreyer, E., Richard, B., Brignolas, F., Montpied, P., Le Thiec, D., 2013 Water-use efficiency of six Populus $\times$ euramericana genotypes: differences in $13 \mathrm{C}$ discrimination between atmosphere and leaf-matter match differences in transpiration efficiency at leaf and whole plant level. Plant, Cell Environ. 36, 87102.

Rasheed, F., Dreyer, E., Richard, B., Brignolas, F., Brendel, O., Le Thiec, D., 2015 Vapour pressure deficit during growth has little impact on genotypic differences of transpiration efficiency at leaf and whole-plant level: an example from Populus nigra L. Plant, Cell Environ. 38, 670-684.

Ripullone, F., Lauteri, M., Grassi, G., Amato, M., Borghetti, M., 2004. Variation in nitrogen supply changes water-use efficiency of Pseudotsuga menziesii and Populus $\times$ euroamericana; a comparison of three approaches to determine wateruse efficiency. Tree Physiol. 24, 671-679.

Ryan, M.G., Stape, J.L., Binkley, D., Fonseca, S., Loos, R.A., Takahashi, E.N., Silva, C.R., Silva, S.R., Hakamada, R.E., Ferreira, J.M., Lima, A.M.N., Gava, J.L., Leite, F.P., Andrade, H.B., Alves, J.M., Silva, G.G.C., 2010. Factors controlling Eucalyptus productivity: how water availability and stand structure alter production and carbon allocation. For. Ecol. Manage. 259, 1695-1703.

Seibt, U., Rajabi, A., Griffiths, H., Berry, J.A., 2008. Carbon isotopes and water use efficiency: sense and sensitivity. Oecologia 155, 441-454.

Sicard, C., Saint-André, L., Gelhaye, D., Ranger, J., 2006. Effects of initial fertilisation on biomass and nutrient content of Norway spruce and Douglas-fir plantations at the same site. Trees 20, 229-246.

Stape, J.L., Binkley, D., Ryan, M.G., 2004. Eucalyptus production and the supply, use and efficiency of use of water, light and nitrogen across a geographic gradient in Brazil. For. Ecol. Manage. 193, 17-31.

Stape, J.L., Binkley, D., Ryan, M.G., Fonseca, S., Loos, R.A., Takahashi, E.N., Silva, C.R., Silva, S.R., Hakamada, R.E., Ferreira, J.M.A., et al., 2010. The Brazil Eucalyptus Potential Productivity Project: influence of water, nutrients and stand uniformity on wood production. For. Ecol. Manage. 259, 1684-1694.

Tausz, M., Merchant, A., Kruse, J., Samsa, G., Adams, M.A., 2008. Estimation of drought-related limitations to mid-rotation aged plantation grown Eucalyptus globulus by phloem sap analysis. For. Ecol. Manage. 256, 844-848.

Vicca, S., Luyssaert, S., Penuelas, J., Campioli, M., Chapin, F.S., Ciais, P., Heinemeyer A., Hogberg, P., Kutsch, W.L., Law, B.E., Malhi, Y., Papale, D., Piao, S.L., Reichstein, M., Schulze, E.D., Janssens, I.A., 2012. Fertile forests produce biomass more efficiently. Ecol. Lett. 15, 520-526.

Wakeel, A., Farooq, M., Qadir, M., Schubert, S., 2011. Potassium substitution by sodium in plants. Crit. Rev. Plant Sci. 30, 401-413.

White, D.A., Battaglia, M., Bruce, J., Benyon, R., Beadle, C., McCrath, J., Kinal, J. Crombie, S., Doody, T., 2009a. Water-use Efficient Plantations Separating the 
Wood from the Leaves. Forest \& Wood Products Australia. Project No. PNC0730708. Melbourne, Australia, 25 p.

White, D.A., Crombie, D.S., Kinal, J., Battaglia, M., McGrath, J.F., Mendham, D.S. Walker, S.N., 2009b. Managing productivity and drought risk in Eucalyptus globulus plantations in south-western Australia. For. Ecol. Manage. 259, 33-44.

White, D.A., McGrath, J.F., Ryan, M.G., Battaglia, M., Mendham, D.S., Kinal, J. Downes, G.M., Crombie, D.S., Hunt, M.E., 2014. Managing for water-use efficient wood production in Eucalyptus globulus plantations. For. Ecol. Manage. 331, $272-280$.
Whitehead, D., Beadle, C.L., 2004. Physiological regulation of productivity and water use in Eucalyptus: a review. For. Ecol. Manage. 193, 113-140.

Wu, Z., Dijkstra, P., Koch, G.W., Peñuelas, J., Hungate, B.A., 2011. Responses of terrestrial ecosystems to temperature and precipitation change: a metaanalysis of experimental manipulation. Global Change Biol. 17, 927-942.

Zhang, Y., Yu, G., Yang, J., Wimberly, M.C., Zhang, X., Tao, J., Jiang, Y., Zhu, J., 2014. Climate-driven global changes in carbon use efficiency. Global Ecol. Biogeogr. $23,144-155$. 